\title{
Response of Facial and Rubrospinal Neurons to Axotomy: Changes in mRNA Expression for Cytoskeletal Proteins and GAP-43
}

\author{
Wolfram Tetzlaff, ${ }^{1}$ Sarah W. Alexander, ${ }^{1}$ Freda D. Miller, ${ }^{2}$ and Mark A. Bisby ${ }^{3}$ \\ 'Departments of Anatomy and Pathology, University of Calgary, Calgary, Alberta, Canada T2N 4N1, ${ }^{2 D e p a r t m e n t s ~ o f ~}$ \\ Anatomy and Cell Biology, University of Alberta, Edmonton, Alberta, Canada T6G 2R7, and ${ }^{3}$ Department of Physiology, \\ Queen's University, Kingston, Ontario, Canada K7L 3N6
}

Neurons confined within the mammalian CNS usually do not regenerate after axonal injury, while axonal regeneration is the rule in the PNS. It has been hypothesized that this may be related to differences in the microenvironment of the PNS versus CNS and to differences in the neuronal response to injury. In order to test the latter hypothesis, we compared changes in gene expression after axotomy in two populations of neurons: rat facial motoneurons and rat rubrospinal neurons. In situ hybridization with cDNA probes for the medium and light neurofilament protein revealed a reduced mRNA content in both facial and rubrospinal neurons at all times investigated (i.e., 1, 2, and 3 weeks after axotomy). On the other hand, mRNAs for actin and tubulin were increased in both neuronal populations during the first week after axotomy. While this increase was sustained in facial motoneurons for several weeks, total tubulin mRNA and actin mRNA were decreased in rubrospinal neurons at 2 and 3 weeks after axotomy, coincident with their atrophy. The developmentally regulated $\mathrm{T} \alpha \mathbf{1}$ tubulin mRNA, which was previously shown to be reexpressed in facial motoneurons after axotomy, was elevated severalfold in axotomized rubrospinal neurons, and increased levels persisted in some rubrospinal neurons as late as 7 weeks after axotomy. Similarly, the developmentally regulated GAP-43 mRNA increased in both axotomized facial and rubrospinal neurons, and increased levels were sustained in some axotomized rubrospinal neurons for at least 7 weeks. The response of rubrospinal neurons to axotomy in the cervical spinal cord is, in the first week, qualitatively similar to the response of facial motoneurons. However, by 2 weeks after axotomy there is a generalized reduction in mRNA levels for all three cytoskeletal proteins that is associated with neuronal atrophy. During this period, mRNA levels for the two specific markers of the

Received Aug. 14, 1990; revised Mar. 7, 1991; accepted Mar. 13, 1991.

We thank Dr. J.-P. Julien for the neurofilament-M cDNA clone, Dr. N. Cowan for the tubulin and neurofilament-L cDNA clones, and Dr. P. Skene for the GAP43 cDNA clone. Dr. W. G. Tatton and P. M. Richardson generously gave us the image analysis software. This work was supported by grants from the Medical Kesearch Council of Canada to W.T. and M.A.B., from the Alberta Heritage Foundation for Medical Research to W.T., and from the Rick Hansen Man in Motion Legacy Fund to M.A.B. W.T. is supported by scholarships from the Alberta Heritage Foundation for Medical Research and from the Medical Research Council of Canada. S.W.A. was supported by an Alberta Heritage Foundation summer studentship. F.D.M. is supported by a scholarship from the Alberta Heritage Foundation for Medical Rescarch. The excellent technical assistance of C. Lconard is gratefully acknowledged.

Correspondence should be addressed to Dr. Wolfram Tetzlaff, Department of Anatomy, University of Calgary, 3330 Hospital Drive Northwest, Calgary, Alberta, Canada T2N 4N1.

Copyright (C 1991 Society for Neuroscience 0270-6474/91/112528-17\$03.00/0 growth state, T $\alpha 1$ tubulin and GAP-43, remain elevated. Thus, axotomy of rubrospinal neurons appears to set in motion two independent events. First, an axotomy signal initiates a cellbody reaction similar to that of PNS neurons, including increased mRNA levels for To1 tubulin and GAP-43. Later, a generalized cellular atrophy and decrease in mRNA levels occur without reversing the specific responses of $T \alpha 1$ and GAP-43 to axotomy. We conclude that the failure of rubrospinal neurons to regenerate is not due to a failure to initiate gene-expression changes characteristic of regenerating peripheral neurons. However, the inability to sustain increased tubulin and actin expression may be related to the abortion of initial sprouting responses of the injured axons.

Mammalian neurons projecting into the PNS (extrinsic neurons) are usually able to regenerate a new axon when lesioned, while those confined within the CNS (intrinsic neurons) typically do not regenerate (Ramon y Cajal, 1959). The reasons for this are poorly understood, and neuronal factors as well as environmental factors are probably involved (Barron et al., 1976, 1977, 1985, 1986, 1989; Richardson et al., 1980; Skene and Willard, 1981; Berry et al., 1986; Politis and Spencer, 1986; Vidal-Sanz et al., 1987; Villegas-Peres et al., 1988; for review, see Aguayo, 1985, 1987; Barron, 1983a,b, 1989; Caroni and Schwab, 1988a,b; Bray and Aguayo, 1989). Extrinsic neurons, which are capable of regeneration, respond to axonal lesions with a variety of biochemical and morphological changes, commonly referred to as cell-body response or axonal reaction (for review, see Lieberman 1971, 1974; Grafstein and McQuarrie, 1978; Kreutzberg, 1982; Barron, 1983a,b, 1989; Grafstein 1983,1986; Tetzlaff et al., 1986). In regenerating extrinsic neurons and regenerating neurons of lower vertebrates, this cell-body response includes dramatic changes in cytoskeletal protein synthesis (Hall et al., 1978; Burrell et al., 1979; Hall, 1982; Quesada et al., 1986; Tesser et al., 1986; Greenberg and Lasek, 1988; Oblinger and Lasek, 1988; Tetzlaff et al., 1988) and cytoskeletal mRNA expression (Neumann et al., 1983; Hoffman et al., 1987; Wong and Oblinger, 1987; Goldstein et al., 1988; Hoffman and Cleveland, 1988; Hoffman, 1989; Miller et al., 1989; Oblinger et al., 1989; Muma et al., 1990; Verge et al., 1990b), as well as the expression of growth-associated proteins such as GAP-43 (Skene and Willard, 1981; Redshaw and Bisby, 1984a; Bisby, 1988; Hoffman, 1989; Tetzlaff et al., 1989; Van der Zee et al., 1989; Verge et al., 1990a; for review, see Benowitz and Routtenberg, 1987; Skene, 1989). In contrast, most studies on intrinsic neurons of the mammalian CNS did not find an increased expression of GAP-43 after axotomy. Axotomy of corticospinal 
neurons and retinal ganglion cells at long distances from their cell bodies failed to produce increased amounts of axonally transported GAP-43 (Skene and Willard, 1981; Redshaw and Bisby, 1984b; Kalil and Skene, 1986; Reh et al., 1987). This correlates with the failure of these neurons to regenerate into peripheral nerve transplants, which provide a permissive growth environment (Richardson et al., 1982, 1984). Recently, Lozano et al. (1987) reported increased GAP-43 immunorcactivity in retinal ganglion cells when axotomized close to the eye, and a significant number of retinal ganglion cells regenerated their axons into peripheral transplants when these were offered close to the retina (Vidal-Sanz et al., 1987). These observations support the hypothesis that the expression of growth-associated proteins, such as GAP-43, represents a prerequisite for axonal regeneration and that the failure to express these genes by CNS neurons after injury relates causally to their failure to regenerate (Skene and Willard, 1981; for reviews, see Barron, 1983a,b, 1989; Skene, 1989). In order to test this hypothesis further, we have now compared changes in cytoskeletal and GAP-43 mRNAs in axotomized neurons of the facial nucleus (extrinsic) and the red nucleus (intrinsic) of the rat using in situ hybridization techniques. The neuron cell bodies of both systems are located within the CNS and are therefore exposed to a common CNS microenvironment.

The facial nerve projects into the PNS and its axons regenerate successfully when crushed at the stylomastoid foramen (Tetzlaff and Bisby, 1989). A further reason for choosing the facial nucleus was that it can easily be isolated by microdissection and analyzed with biochemical techniques (Tetzlaff and Kreutzberg $1984,1985)$. In agreement with studies of peripheral ganglia (Hoffman et al., 1987; Greenberg and Lasek, 1988; Oblinger and Lasek, 1988), we found an increased ${ }^{35}$ S-methionine incorporation into actin and tubulin and a decreased incorporation into neurofilament proteins after axotomy (Tetzlaff et al., 1988). Here, we will show that these previously determined changes in methionine incorporation correlate closely with changes in mRNA levels within the axotomized motoneurons using quantitative in situ hybridization and Northern blot analysis.

These results provide essential baseline data for comparison with the responses of the intrinsic ncurons of the red nucleus to axotomy. The rubrospinal system of the rat was chosen because it is composed of a circumscribed, easily identifiable group of neurons within the midbrain amenable to image analysis. The axons are almost completely ( $>99 \%$ ) crossed (Brown, 1974; Huisman et al., 1981), and thus only those rubral neurons contralateral to a spinal hemisection are axotomized. The caudal magnocellular pole is anatomically well defined (Reid et al., $1975 \mathrm{a}, \mathrm{b})$, and the comparison with a nonaxotomized contralateral side within the same brainstem section is possible. The rubrospinal axons do not regenerate successfully across a spinal cord lesion in the adult (Barron et al., 1989), but they do display some regenerative potential, sending out numerous sprouts soon after injury (Barron et al., 1989), and some can regenerate into the permissive environment of a peripheral nerve transplant (Richardson et al., 1984). Nevertheless, previous investigations of injured rubral neurons have so far indicated that their response to injury is "regressive" in nature: no increase in RNA synthesis is seen (Barron, 1983a,b, 1989; Barron et al., 1976, 1989); the cells shrink, but little neuronal death occurs (Prendergast and Stelzner, 1976; Barron et al., 1989; Xu and Martin, 1990). With this background, we expected to see major differences in the expression of cytoskeletal proteins and GAP-43
mRNAs in rubrospinal axons after axotomy, when compared with facial motoneurons. Our results show that the initial response to axotomy is qualitatively similar in the two types of neurons, but that during the second week after axotomy, rubrospinal neurons reduce expression of tubulin and actin mRNAs to subnormal values. Although these intrinsic neurons initially respond appropriately to axon injury by increased expression of regeneration-associated genes, this is not sufficient to permit their regeneration in the absence of a supportive environment.

\section{Materials and Methods}

The cDNA clones were a generous gift of Dr. J.-P. Julien [mediummolecular-weight neurofilament protein (NFM); see Julien et al., 1986], Dr. N. Cowan (NF68; see Lewis and Cowan, 1985; $\mathrm{M} \alpha \mathrm{l} \alpha$-tubulin and M $\beta 2 \beta$-tubulin; see Lewis et al., 1985), Dr. G. Schulz (actin; see Minty et al., 1981), and Dr. Pate Skene (GAP-43; Basi et al., 1987). Fluorogold was obtained from Fluorochrome Inc., Englewood, Colorado, and fast blue was from Sigma, St. Louis, Missouri.

Animal surgery. Male Sprague-Dawley rats (230-300 gm) were used throughout this study. They were kept in a 14-hr:10-hr light/dark cycle and fed a standard diet and water ad libitum.

Facial nerve lesions. The rats were anesthetized with sodium pentobarbital $(32 \mathrm{mg} / \mathrm{kg})$ plus chloral hydrate $(150 \mathrm{mg} / \mathrm{kg})$, and the left facial nerve was exposed at the stylomastoid foramen. For crush lesions, the nerve was crushed twice with a pair of Dumont \#5 forceps for $30 \mathrm{sec}$, 2-3 mm distal from the stylomastoid foramen (about 12-14 mm distal to the motoneurons in the brainstem). In selected animals, facial nerves distal to the lesion were processed for immunocytochemical staining for neurofilaments $2 \mathrm{~d}$ after lesioning to verify that the nerves were completely crushed (data not shown). For nerve resections, the nerve was transected 2-3 mm distal from the stylomastoid foramen, and a $1-\mathrm{cm}$ segment distal to the transection was excised in order to impede regeneration. The animals were killed between $12 \mathrm{hr}$ and $28 \mathrm{~d}$ after facial nerve lesion by intracardiac perfusion with $0.1 \mathrm{M}$ phosphatebuffered ( $\mathrm{pH} 7.4$ ) 4\% paraformaldehyde under deep chloral hydrate anesthesia. In some cases, the brainstem was removed fresh and rapidly frozen.

Kubrospinal tract lesions. The rats were deeply anesthetized with sodium pentobarbital $(32 \mathrm{mg} / \mathrm{kg})$ plus chloral hydrate $(150-180 \mathrm{mg} / \mathrm{kg})$ and under strictly aseptic conditions the $\mathrm{C} 3$ vertebrae were laminectomized to expose the spinal cord. The left lateral funiculus of the spinal cord was transected with a \#11 scalpel blade. In some animals, a $1-\mu 1$ depot of Fluoro-gold (5\%) or fast blue (3-5\%; Kuypers and Huisman, 1984) was applied to the lesion site by using a small piece of dye-soaked Gelfoam. This application allowed the positive identification of rubrospinal neurons through retrograde transport from the lesion site and is compatible with the in situ hybridization procedure. The gap in the dura was covered with Gelfoam, and subsequently the muscular layers and the skin were sutured. During the postoperative period, bladder function was usually not impaired, but was replaced by manual expression of urine if necessary. In rare cases of wound infections, the rat was immediately killed. The extent of the spinal cord lesion was examined post-mortem in some animals. In most animals, it included the lateral, anterior, and parts of the dorsal funiculi. Thus, the lesion was in most cases an incomplete hemisection and included in all cases the lateral funiculus.

In situ hybridization. The protocol of Miller et al. (1987) was used. with some modifications. The rats were killed by paraformaldehyde perfusion, and the cryoprotected brains were rapidly frozen in dry icecooled isopentane, then cut on a cryostat at $10 \mu \mathrm{m}$. In the rubrospinal series, only those sections of the caudal magnocellular pole of the red nucleus (most caudal $400 \mu \mathrm{m}$ ) were selected and analyzed. Prehybridization solution contained 50\% formamide, $25 \mathrm{~mm}$ PIPES (Boehringer Mannheim) buffer ( $\mathrm{pH} 6.8$ ), 25 mM EDTA, $0.75 \mathrm{M} \mathrm{NaCl}, 5 \times$ Denhardt's solution (Maniatis et al., 1982), $100 \mathrm{~mm}$ dithiothreitol, $250 \mu \mathrm{g} / \mathrm{ml} t \mathrm{RNA}$ from yeast, and $250 \mu \mathrm{g} / \mathrm{ml}$ salmon sperm DNA (denatured). For hybridization, the same solution was used containing $10-20 \mathrm{ng} / \mathrm{ml}{ }^{35} \mathrm{~S}$ radiolabeled cDNA probe prepared by random hexanucleotide priming (Feinberg and Vogelstein, 1983).

Controls were incubated with ${ }^{35} \mathrm{~S}$-labeled plasmid DNA and revealed low background labeling with no specific pattern. Moreover, pretreatment of the slides with RNase A eliminated the signals over the neurons and left behind background labeling. 

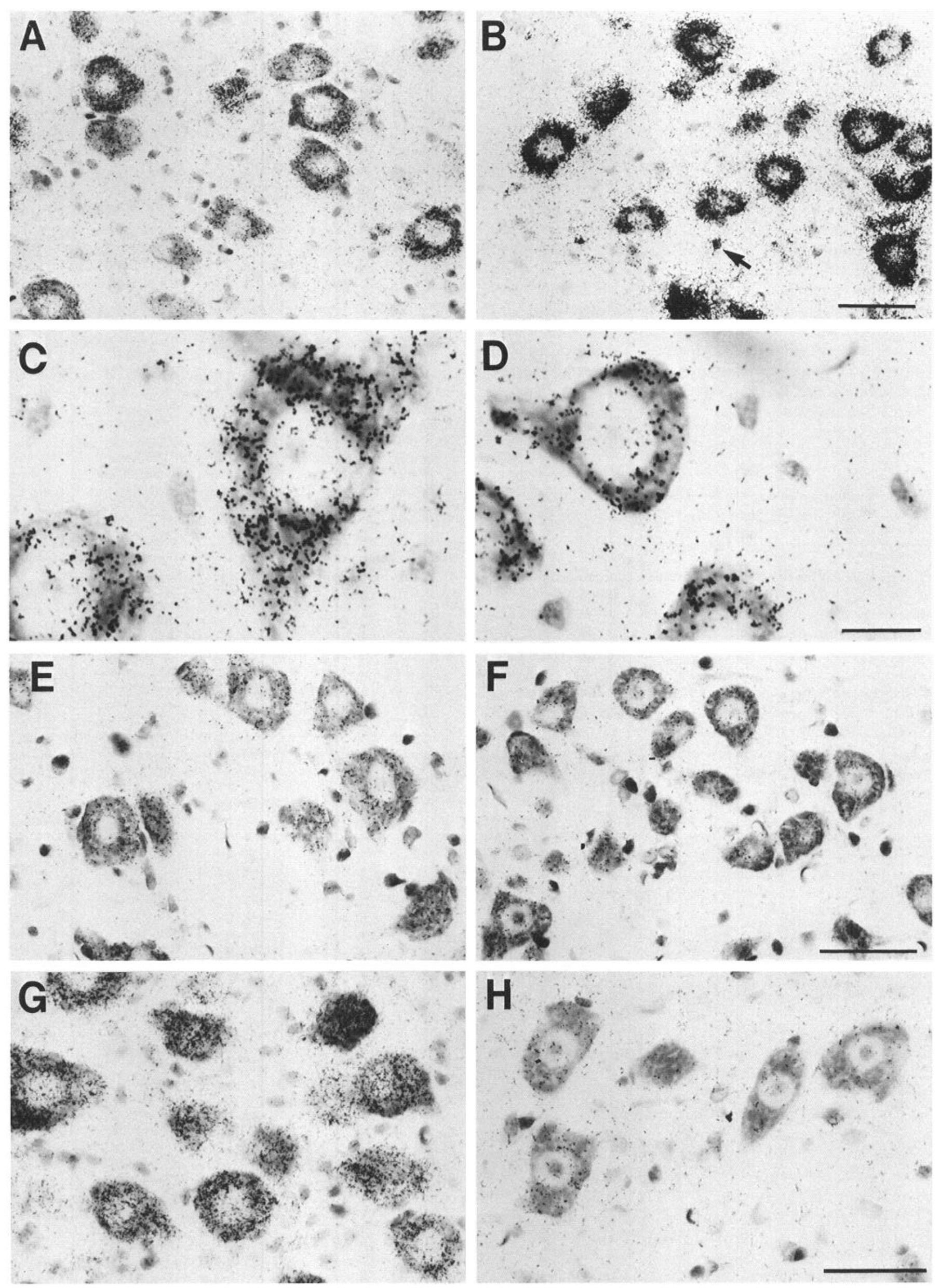
Radioautography. After in situ hybridization, the slides were exposed to Kodak XAR 5 film for $1-3 \mathrm{~d}$. These film radioautographs gave an idea of the strength of the radioactive signal and allowed an estimation of an appropriate exposure time for emulsion radioautography. The latter was done according to routine protocols by dipping the slides in Kodak NTB2 emulsion diluted by $1: 1$ with distilled water at $42^{\circ} \mathrm{C}$. After $1-4$ weeks exposure, the slides were developed in D19 for $3 \mathrm{~min}$ at $20^{\circ} \mathrm{C}$ and fixed in Kodak Rapidfix. The facial nucleus slides were subsequently stained with cresyl violet, dehydrated, and embedded in Permount or DePeX (BDH). Because the fluorescent retrograde tracers used in the rubrospinal study were easily washed out during hybridization, staining, and dehydration, these sections were analyzed first in the fluorescence microscope (Leitz Orthoplan, Ploemopak Filter A) in order to identify and map the labeled rubrospinal neurons. After in situ hybridization, prior to staining, photography using epifluorescence for the label combined with dark-field illumination for the silver grains was carried out.

Quantification of in situ hybridizations. Silver grains were quantitated by measuring the relative fraction of the cytoplasmic area of individual neurons that was occupied by emulsion grains using a computerized image analysis system that we have used in previous studies (Verge et al., 1990a,b). Because the selection of density levels of cells used for the measurement of the area fraction occupied by grains could be subject to bias on the part of the observer, all identification tags on the slides were obliterated after coding; thus, the observer was unaware of experimental procedure, survival time, and probe used. The mean values obtained by two independent observers from the same section differed by less than $20 \%$. The cytoplasmic and nuclear areas were measured for each neuron, permitting the calculation of the cytoplasmic volume, assuming that the cell and nucleus were approximately spherical. Because neurons change size after axotomy, the same amount of signal per cell can appear diluted (smaller fraction of the measured area occupied by grains) if the cell swells, or can appear concentrated if the cell shrinks. In order to get an estimate of the total grain signal per cell, the fractional area occupied by grains was multiplied by the cytoplasmic volume. This calculated signal per cell (counts per cell) was plotted against the calculated cytoplasmic volume of the cell. Finally, the mean counts per cell of measured neurons from the experimental side (injured) were expressed as a percentage of the equivalent mean value from the control side. Thus, each point in the diagrams showing the percentage of control is based on 20-30 cells from each side of an individual animal. In the case of the red nucleus, the analysis was restricted to the caudal $400 \mu \mathrm{m}$ of the red nucleus, which contains mainly magnocellular neurons that project to the spinal cord. In cases where retrograde tracers had been applied, only labeled neurons were analyzed. These sections confirmed that the majority ( $>90 \%$ ) of magnocellular neurons were axotomized by cervical lesions at $\mathrm{C} 3$. Because the caudal pole of the red nucleus contains fewer neurons than the facial nucleus, only $10-30$ cells from each animal could be quantitated after hybridization with one of the seven different cDNA probes used. Student's $t$ test was applied to the mean counts per cell values (not the normalized data) to detect significant changes between experimental and control neurons. To detect significant differences between percentage changes for different probes (e.g., $\alpha$-tubulin vs. $\beta$-tubulin), the nonparametric Wilcoxon-MannWhitney test was used. The criterion for significance was $p<0.05$.

The comparison with the contralateral side implies that the effects of injury are entirely unilateral, which remains to be shown for each mRNA analyzed here. Variations between animals and between slides did occur, and in order to compare two animals, sections of each have to be on the same slide and processed identically. Thus, a control series of four unoperated and four unilaterally lesioned (facial nerve) rats was generated separately in order to search for possible contralateral effects of axotomy. Sections from one unlesioned and one lesioned animal were mounted on the same slide and subjected to identical hybridization conditions. There was no indication of a contralateral increase $7 \mathrm{~d}$ after facial nerve axotomy (data not shown). Because this result contrasted with the film-radioautographic study on $\alpha$-tubulin expression in the rat facial nucleus by Pearson et al. (1988), we performed film radioautography, light microscopical analysis, and RNA dot blot analysis on facial nuclei of operated versus unoperated rats and could not find any evidence for a contralateral effect at $7 \mathrm{~d}$ after lesion (data not shown). Therefore, we consider the expression of our data in the form of "percentage of contralateral" is justifiable. If a small, nondetectable contralateral effect existed, the axotomy-induced changes presented in this study would be even greater.

$R N A$ blotting. Total cytoplasmic RNA was extracted from four pooled isolated facial nuclei according to the phenol/chloroform/isoamyl alcohol technique of Schibler et al. (1980). Equal amounts of RNA were fractionated by electrophoresis on $1.2 \%$ agarose gels in the presence of 1 M formaldehyde (Rave et al., 1979) and blotted onto nitrocellulose by capillary transfer (Thomas, 1980). The filters were covered for $2 \mathrm{hr}$ at $43^{\circ} \mathrm{C}$ in prehybridization solution (see above). Hybridization was performed for 12-16 hr using the same solution with the addition of a ${ }^{35}$ S-labeled cDNA probe $\left(5 \times 10^{6} \mathrm{cpm} / \mathrm{ml}, 10-20 \mathrm{ng}\right.$ probe $/ \mathrm{ml}$; see above). Posthybridization washes were carried out with $4 \mathrm{x}, 2 \mathrm{x}, 1 \mathrm{x}, 0.5 \mathrm{x}$, and 0.1x SSC (Maniatis et al., 1982) at $45^{\circ} \mathrm{C}$. Dried filters were exposed to Kodak XAR5 x-ray film for 1-2 weeks and developed. The signals were quantified by densitometry using an LKB laser densitometer.

\section{Results}

\section{Changes in neurofilament $m R N A$}

Facial motoneurons. Changes in mRNA levels for the lightmolecular-weight neurofilament (NFL) and NFM were analyzed between $12 \mathrm{hr}$ and $21 \mathrm{~d}$ after facial nerve axotomy. An example of in situ hybridization to NFM is displayed in Figure 1, $A$ and $B$. The axotomized motoneurons are increased in size and contain a lower density of silver grains (Fig. $1 A$ ).

Figure 2, $A$ and $B$, shows the results of quantification of the in situ hybridizations. The relative decrease of the NFL and NFM hybridization signals was already apparent $12 \mathrm{hr}$ after axotomy, when levels were at $74-80 \%$ of control; however, none of these values were significantly different from contralateral. By $24 \mathrm{hr}$, the average neuronal neurofilament mRNA content was between $45 \%$ and $92 \%$ of contralateral, and this difference was significant $(p<0.05)$ in some animals. NFM and NFL hybridization signals dropped further to reach levels between $10 \%$ and $40 \%$ on days 5 and 7 . In cases of successful regeneration (i.e., after a crush lesion), the values recovered to between $43 \%$ and $82 \%$ by $14 \mathrm{~d}$ and $71 \%$ and $113 \%(78-145 \%$, NFL) by 21 $\mathrm{d}$. This is in contrast to those cases where resection prevented successful regeneration; for these, the signal levels stayed between $5 \%$ and $30 \%$ for both messages.

Northern blot analysis for NFM (Fig. 3) revealed a decrease to $20.5 \%$ of the control side $7 \mathrm{~d}$ after resection (Fig. $2 \mathrm{~B}$, solid star) and to $66 \%$ after crush (open star).

Rubrospinal neurons. The in situ hybridization signal for NFM and NFL mRNA was decreased at all time points. This is obvious in the dark-field micrograph shown in Figure 4, $A$ and $B$, taken $10 \mathrm{~d}$ after rubrospinal tract lesion and in the bright-field micrographs in Figure 4, $C$ and $D$. (The combination of fast blue and NFM in situ hybridization is displayed in Fig. 9A,B.) Most labeled cells display reduced grain densities. The quan-

\footnotetext{
Figure 1. Light microscopic radioautography of facial motoneurons after in situ hybridization with probes to NFM $(A, B)$, actin $(C, D), \alpha$-tubulin $(E, F)$, and GAP-43 $(G, I)$. The axotomized facial motoneurons arc displaycd on the left, and their contralateral counterparts are presented on the right. $A$ and $G$ were taken at $7 \mathrm{~d}$ after resection; $C$ and $E$, at $5 \mathrm{~d}$ after resection. The perikarya are enlarged on the axotomized side. Note the decreased NFM hybridization signals over the axotomized motoneurons $(A)$, while the actin $(C), \alpha$-tubulin $(E)$, and GAP-43 $(G)$ hybridization signals are increased. Little signal is associated with glial cells. The arrow in $B$ points to a presumed dendritic profile. Scale bars: $50 \mu \mathrm{m}$ for $A, B$, $E-H ; 20 \mu \mathrm{m}$ for $C, D$
} 

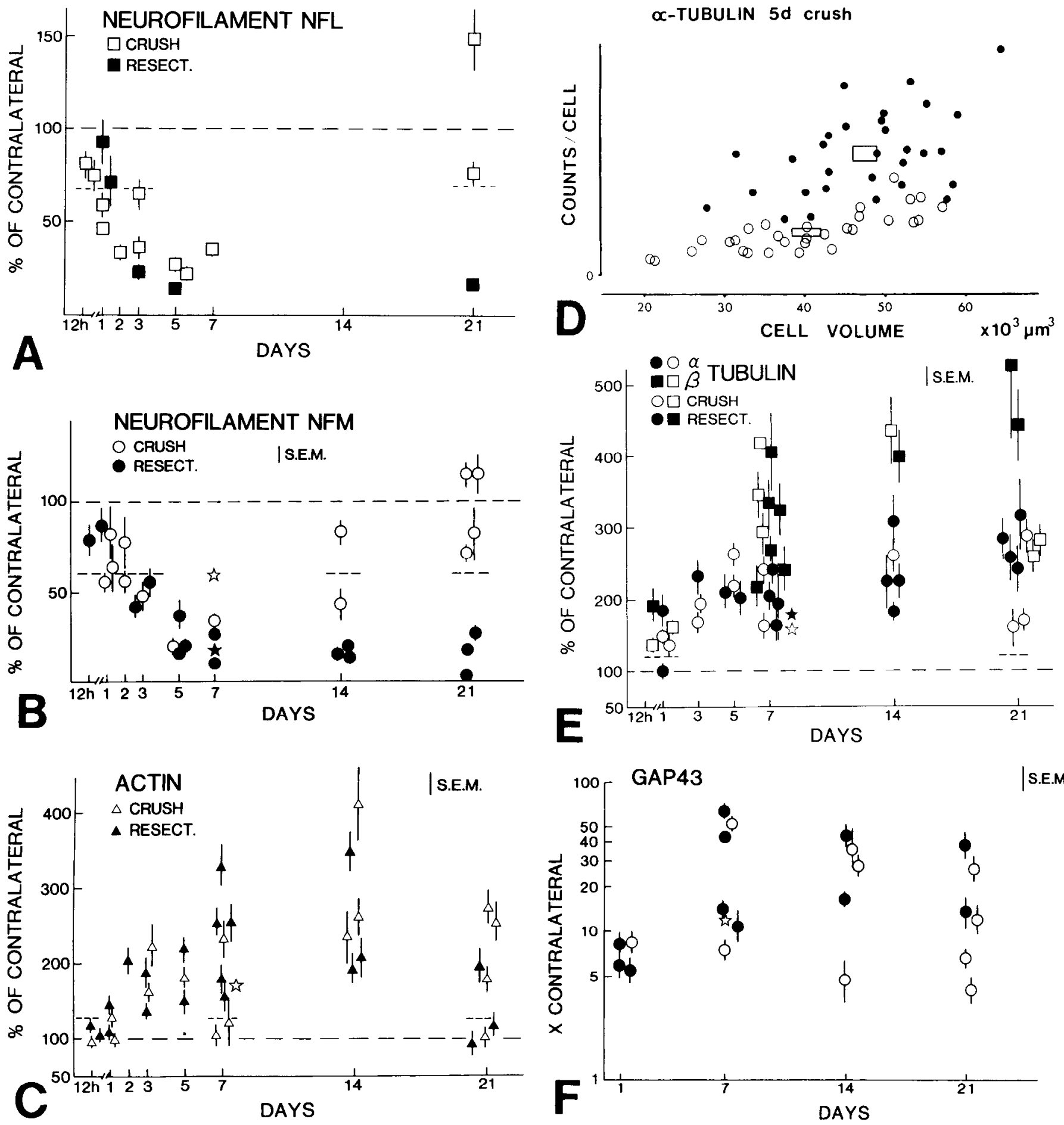

Figure 2. Quantification of in situ hybridizations of facial motoneurons with cDNA probes to NFL $(A)$, NFM $(B)$, actin $(C), \alpha$-tubulin $(D, E)$, and GAP-43 $(F)$. D gives an example of the analysis of individual motoneurons. The cell volume is the cytoplasmic volume and is plotted against the number of counts per cell. In $D$, solid circles represent individual axotomized neurons, and open circles, contralateral intact neurons. Note the increase in cell volume and counts/cell for $\alpha$-tubulin mRNA, $5 \mathrm{~d}$ postcrush. The boxes in $D$ indicate mean \pm SEM for volume and counts. Each symbol in $A-C, E$, and $F$ is based on a similar scatterplot ( $>25$ cells) from individual animals and represents the mean counts/cell for axotomized neurons expressed as percentage of mean counts in contralateral neurons from the same animal. Open symbols, facial nerve crush; solid symbols, resection; vertical bars, SEM. Values above the small broken lines were significantly different from contralateral $(t$ test, $p<0.05)$. The stars represent percentage change of the Northern blot signal of pooled facial nuclei taken $7 \mathbf{d}$ after nerve crush; Northern blots are shown in Figure 3 .

tification of these neurofilament hybridizations revealed values around $25-65 \%$ during the first week (Fig. $4 E, F$ ). In all except one animal, significant reductions in neurofilament mRNA were found at $14 \mathrm{~d}$ and $21 \mathrm{~d}$. By this time, values around $20-40 \%$ of contralateral were typically observed (Fig. $4 F$ ).

\section{Changes in actin $m R N A$}

Facial motoneurons. Actin mRNA hybridization signals were increased in facial motoneurons after axotomy. By $7 \mathrm{~d}$, the axotomized motoneurons were larger and more basophilic, but 


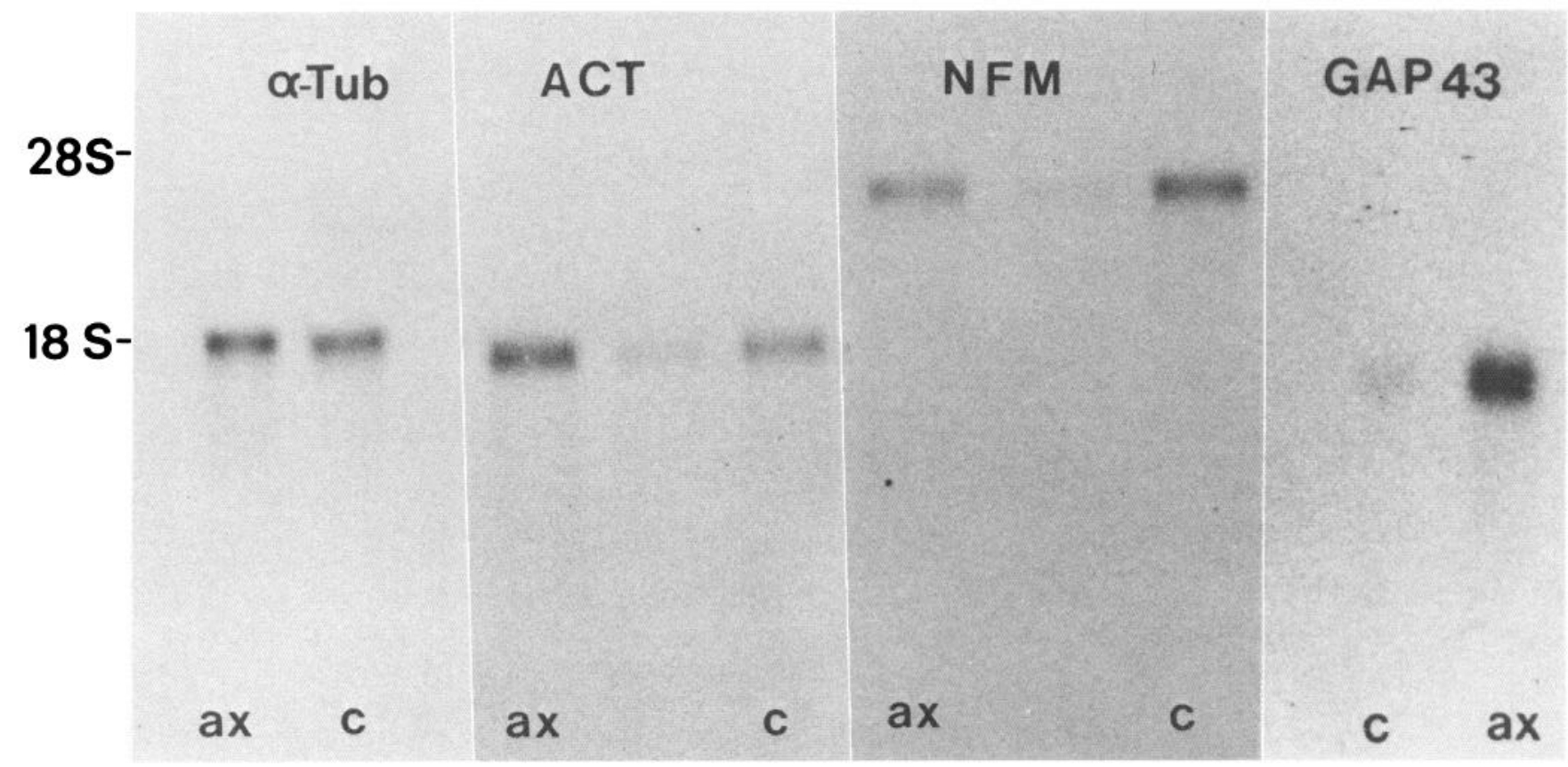

Figure 3. Northern blot analysis of total RNA from four pooled facial nuclei transferred onto nitrocellulose and probed with the $\alpha$-tubulin ( $\alpha$ $T u b$ ), actin $(A C T)$, NFM, and GAP-43 cDNA probes. In case of actin and NFM, the same membrane was hybridized twice, and RNA from an equal volume of tissue from the reticular formation located between the facial nuclei was loaded in the middle lane. All probes give a single hybridization band at $1.8 \mathrm{~kb}, 1.7 \mathrm{~kb}, 3.4 \mathrm{~kb}$, and $1.4 \mathrm{~kb}$, respectively. The intensity of the actin, $\alpha$-tubulin, and GAP-43 signal increased in the axotomized (crush) facial nucleus, while the NFM signal decreased. The percentage changes are displayed as stars in Figure 2. ax, axotomized (crush), $7 \mathrm{~d} ; c$, contralateral, intact.

did not display the classical appearance of chromatolysis (Fig. $1 C, D)$. They contained significantly more silver grains per cell than the contralateral counterparts (Fig. $1 C, D$ ). Only a few grains were associated with glial cells (Fig. $1 C, D$ ). Quantification of the actin in situ hybridization data is displayed in Figure $2 C$. Actin in situ hybridization signals were between $95 \%$ and $117 \%$ of contralateral $12 \mathrm{hr}$ after lesion. The values varied between $100 \%$ and $145 \%$ of contralateral on day 1 and increased to around $200 \%$ (range, 106-269\%) on days 2, 3, 5, and 7 . With the exception of two animals ( $7 \mathrm{~d}$ after crush), data from all others showed significantly higher values for axotomized neurons than for contralateral unoperated neurons. At $14 \mathrm{~d}$, actin mRNA signal was between $193 \%$ and $413 \%$ of contralateral (all $p<0.02$ ), with no obvious difference between animals that received facial nerve crush or resection. At $21 \mathrm{~d}$, values between $90 \%$ and $275 \%$ were found. Regardless of the type of lesion, the mRNA levels appeared to be returning to normal.

Densitometric analysis of Northern blots of four pooled facial nuclei revealed an increase to $165 \%$ of contralateral $7 \mathrm{~d}$ after crush. This is represented as the star in Figure $2 C$. The Northern blot is shown in Figure 3 and demonstrates that only a single message size $(\approx 1.7$ kilobases) hybridized with the actin probe, which corresponds to the size of the $\alpha$-actin mRNA (Minty et al., 1981).

Rubrospinal neurons. Seven days after lesion, rubrospinal neurons revealed a clear increase of the silver grains reflecting actin hybridization signal over the axotomized cells when viewed under dark-field illumination (Fig. $5 A, B$ ). In bright-field illumination, these neurons clearly showed central chromatolysis and higher grain density (Fig. $5 C, D$ ). Silver grain quantifications revealed a significant increase by day 8 to about twofold (Fig. $5 E, F)$. However, this actin mRNA increase was not seen in all cells (Fig. $5 E$ ), and in animals with retrograde labeling from the lesion site, some labeled cells did not display increased in situ hybridization signals (data not shown). At $14 \mathrm{~d}$ and $21 \mathrm{~d}$, the majority of the rubral neurons displayed lower actin hybridization signals than those on the nonaxotomized contralateral side. At these later time points, the cytoplasmic volume of the neurons on the axotomized side was significantly reduced to $65 \%$ (14 d) and 63\% (21 d; $p<0.01)$, and though the grain density was only slightly reduced or even similar to the contralateral side, the grain counts per cell were significantly $(p<0.02)$ reduced compared to contralateral (Fig. $5 F$ ), and also compared to normal rubrospinal neurons from nonoperated animals (processed together on the same slide).

\section{Changes in total tubulin and Tal tubulin $m R N A$}

Facial motoneurons. In situ hybridization of facial motoneurons with probes for $\alpha$-tubulin and $\beta$-tubulin revealed increased neuronal mRNA levels for both tubulin families; $\alpha$-tubulin is shown in Figure 1, $E$ and $F$. Both tubulin probes used (M $\alpha 1$ and $\mathrm{M} \beta 2)$ contain conserved sequences shared between different genetic tubulin isotypes (Lewis et al., 1985; Villasante et al., 1986) and therefore hybridize with all $\alpha$-tubulin and $\beta$-tubulin messages, respectively. The predominant neuronal localization of the tubulin mRNAs is obvious; only a few glial cells reveal higher grain levels than the tissue background. Quantification of tubulin in situ hybridizations revealed for most animals levels higher than contralateral (Fig. 2D). However, one animal with a nerve resection was not different from contralateral by $24 \mathrm{hr}$. All other values at this and the later time points were significantly elevated. The relative increase for $\beta$-tubulin was significantly higher than for $\alpha$-tubulin at days 7, 14, and 21 when compared within individual animals. There was no obvious 

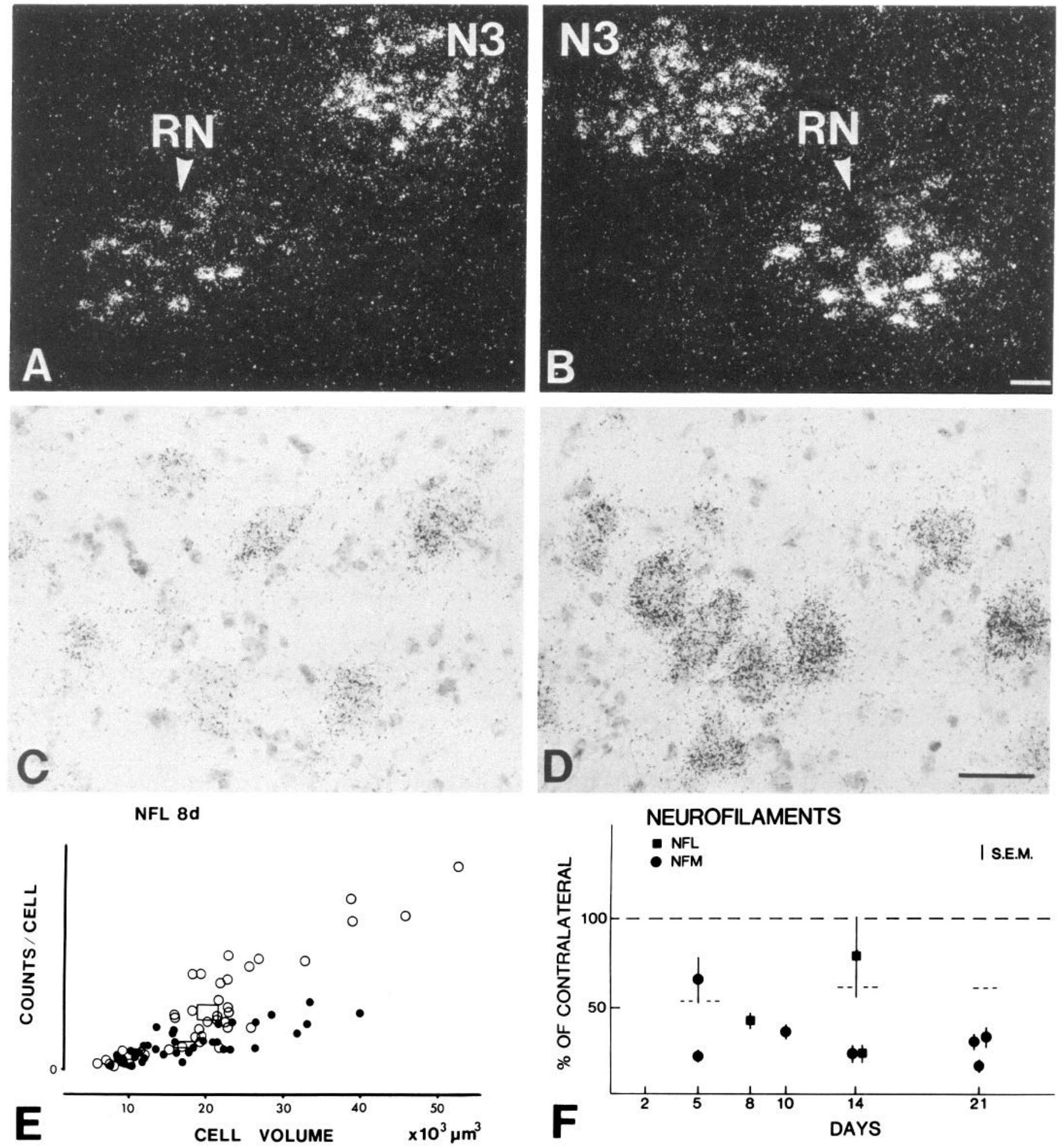

Figure 4. Light microscopic radioautography of rubral neurons after in situ hybridization to a radiolabeled NFM cDNA probe $(A-D)$. The axotomized side is displayed in $A$ and $C$. Dark-field illumination in $A$ and $B$ shows a marked decrease in hybridization signal in the caudal red nucleus $(R N$; arrowheads) at $10 \mathrm{~d}$ after axotomy. Bright-field illumination in $C$ and $D$ shows decreased density of silver grains over chromatolytic rubral neurons $(C)$. $C$ and $D$ were taken from a section adjacent to $A$ and $B$. N3 is the oculomotor nucleus nerve. Scale bars: $100 \mu \mathrm{m}$ for $A$ and $B$; $50 \mu \mathrm{m}$ for $C$ and $D$. $E$ shows a scatter plot of quantitative $i n$ situ hybridization of rubrospinal neurons to an NFL cDNA probe, $8 \mathrm{~d}$ after rubrospinal tractotomy at C3. Symbols are as in Figure 2D. $F$ shows changes in mean counts/cell shown as axotomized neuron values as a percentage of uninjured contralateral neuron values. The vertical bars indicate SEM for $>20$ cells from individual animals. Values below the short broken lines were significantly different from uninjured $(t$ test). 

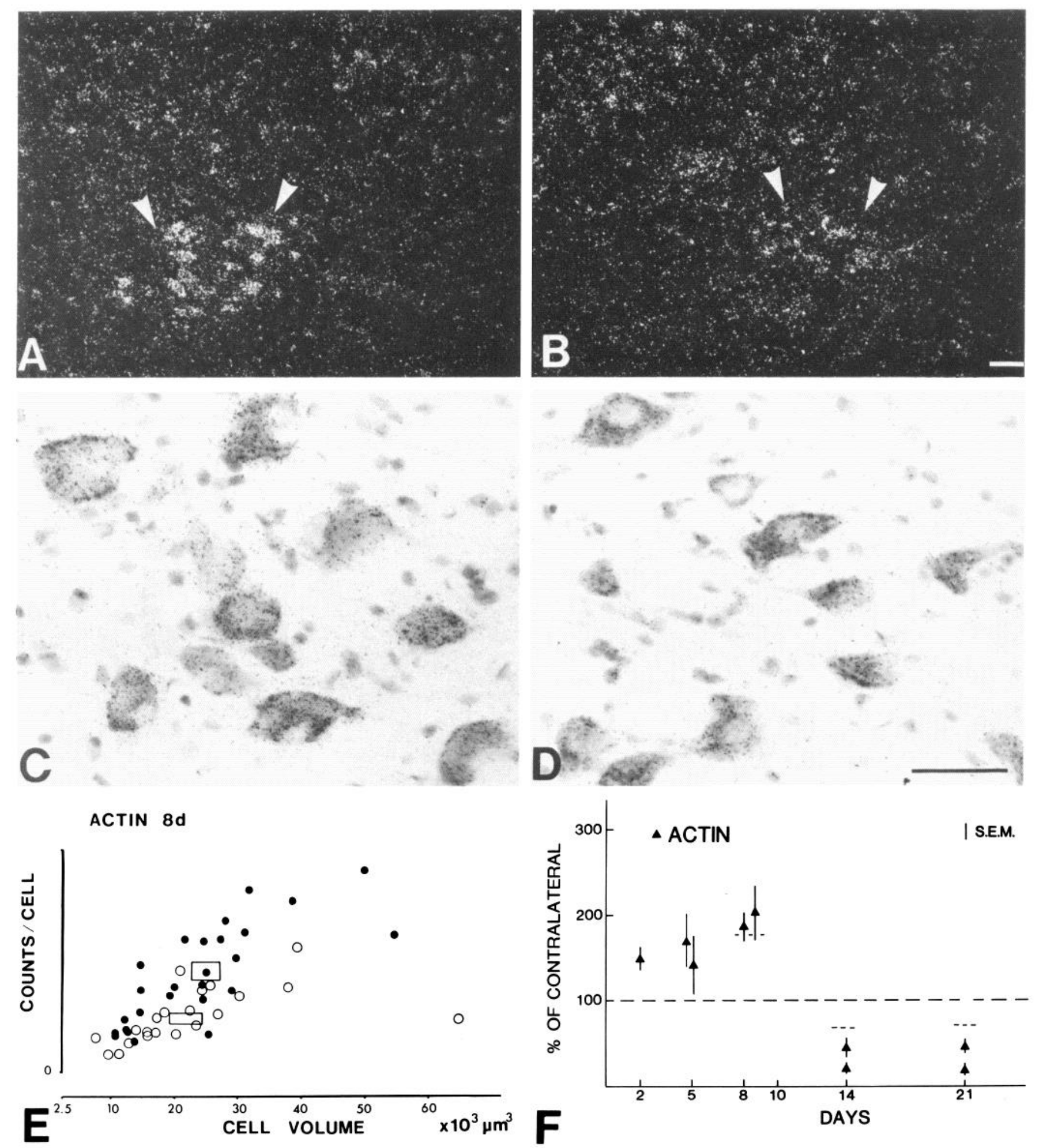

Figure 5. Light microscopical radioautography of rubral neurons after in situ hybridization to a radiolabeled actin cDNA probe. The axotomized side is displayed in $A$ and $C$. Dark-field illumination in $A$ and $B$ shows a marked increase in hybridization signal in the caudal portion of the red nucleus at $8 \mathrm{~d}$ after axotomy (arrowheads in $A$ ). Bright-field illumination in $C$ and $D$ shows increased density of silver grains over chromatolytic rubral neurons $8 \mathrm{~d}$ after axotomy $(C)$. Scale bars: $100 \mu \mathrm{m}$ for $A$ and $B, 50 \mu \mathrm{m}$ for $C$ and $D$. $E$ shows a scatter plot of quantitative in situ hybridization of rubrospinal neurons to an $\alpha$-actin cDNA probe, $8 \mathrm{~d}$ after spinal hemisection at C3. Symbols are as in Figure $2 D$. $F$ displays changes in mean counts/cell. Values above ( $8 \mathrm{~d})$ and below (14 d and $21 \mathrm{~d})$ the short stippled lines were significantly different from contralateral. 

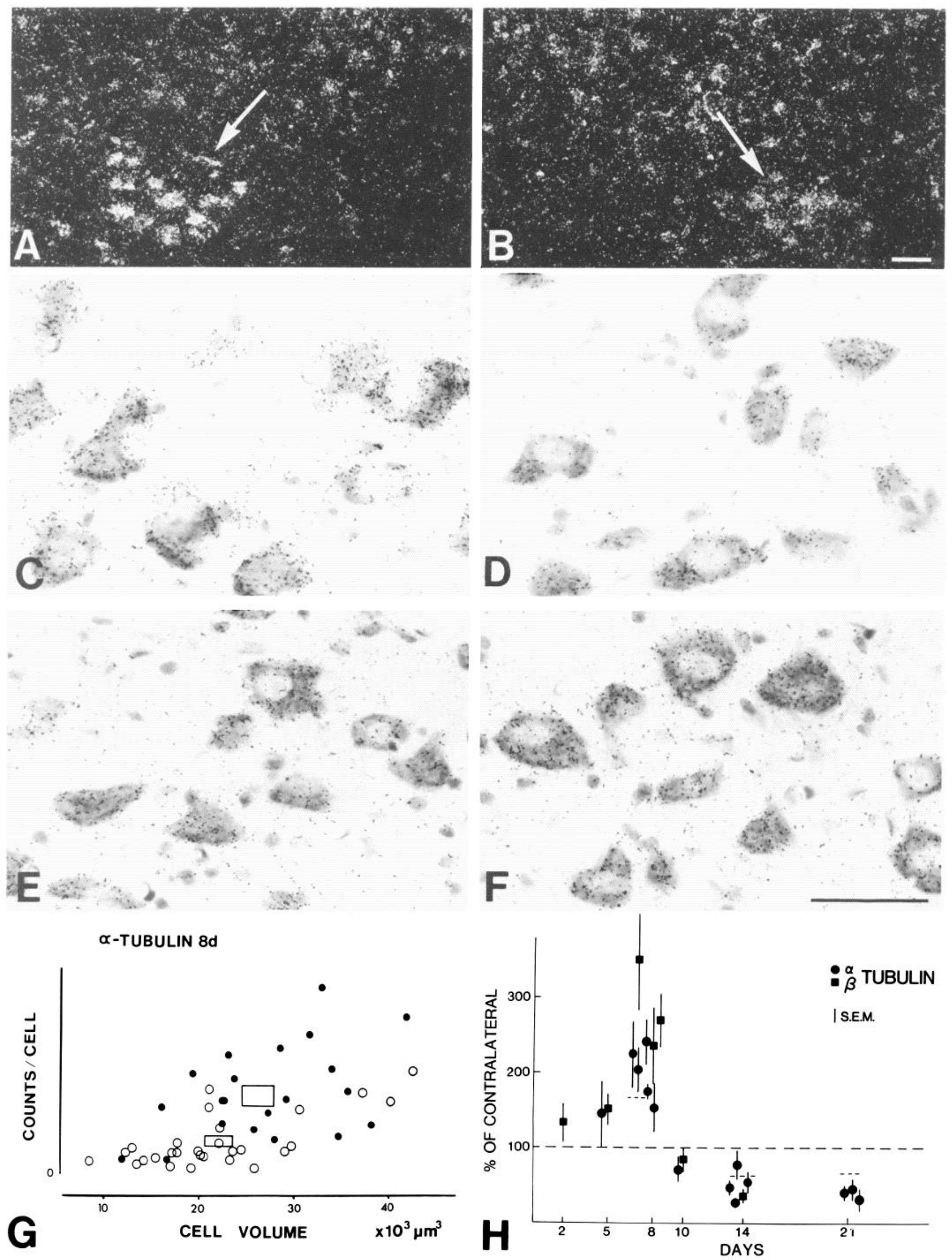

ग्र:
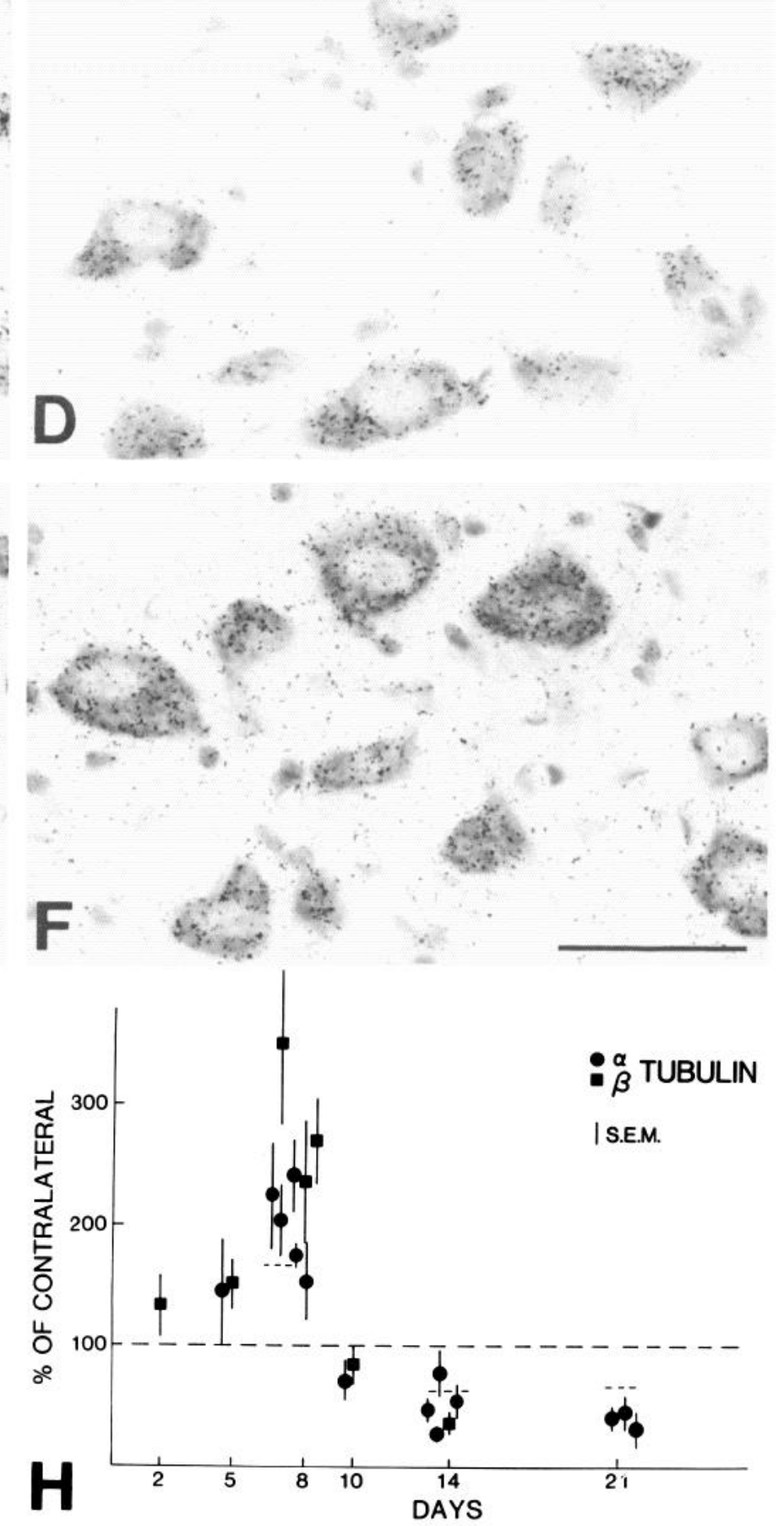
difference between the tubulin mRNA increase in crushed versus resected motoneurons at early time points, but by $21 \mathrm{~d}$ the mRNA levels were lower in crushed than in resected facial motoneurons. The regenerating axons of the crushed motoneurons reach their targets by $11-14 \mathrm{~d}$ after facial nerve crush, as shown by the return of whisker movement. The relative $\alpha$-tubulin mRNA increase in Northern blots of four pooled facial nuclei are displayed as stars in Figure $2 E$. The signal increased to $164 \%$ of contralateral after resection and $158 \%$ after crush (both at $7 \mathrm{~d}$ ), which was in good agreement with the in situ hybridization data.

Rubrospinal neurons. We found an increased in situ hybridization signal for $\alpha$ - and $\beta$-tubulin mRNA (total $\alpha$-tubulin, total $\beta$-tubulin) in the axotomized rubrospinal neurons during the first week after the lesion (Fig. 6A-D; see also Fig. 9C,D). As seen in the scatter plot in Figure $6 G$, this involved the majority of the rubrospinal neurons within the caudal, magnocellular part of the nucleus from which the measurements were taken. A small increase in volume to $108 \pm 4.9 \%$ was observed during this first week. At both $14 \mathrm{~d}$ and $21 \mathrm{~d}$, the axotomized rubral neurons displayed lower in situ signals per cell than the contralateral not axotomized neurons (Fig. 6E,F). As with actin, this was mainly due to a reduced cellular volume, which in combination with an equivalent or slightly diminished grain density resulted in a significant reduction of hybridization signals per injured cell (Fig. 6H).

The fall of actin and total tubulin expression after 8-14 d could be the result of a general depression of RNA synthesis or indicatc a failure to sustain the specific changes in gene expression associated with the cell body reaction to injury. Therefore, we analyzed the expression of $\mathrm{T} \alpha 1$ tubulin $\mathrm{mRNA}$, which represents a genetic $\alpha$-tubulin isotype (Lemischka et al., 1981) and is highly expressed in developing brain (Miller et al., 1987). Recently, we demonstrated that it is reexpressed in adult facial motoneurons after axotomy (Miller et al., 1989). Using a cDNA probe generated from the $3^{\prime}$ nontranslated sequences unique to this isotype, we found an increase in T $\alpha 1$ tubulin mRNA in axotomized rubrospinal neurons (Fig. $7 E, F$ ). This increase is sustained beyond the period when actin and total tubulin mRNA levels decrease (Fig. $8 B, C$ ). Even at 7 weeks, some, but not all, axotomized rubrospinal neurons display increased signals with the $\mathrm{T} \alpha 1$ tubulin probe (Fig. $9 G, H$ ).

\section{Changes in GAP-43 $M R N A$}

GAP-43 (also known as B50, F1, pp46, neuromodulin) has previously been shown to be expressed in the developing nervous system, and in regenerating extrinsic neurons, but most studies analyzing its expression in intrinsic CNS neurons have reported no increase after axotomy (for review, see Skene, 1989).

Facial motoneurons. Intact motoneurons showed little more than background levels of silver grains, while the axotomized cells displayed high levels of GAP-43 in situ hybridization signal (Fig. 1G,H). Quantification of the in situ signal demonstrated a 6-10-fold increase compared to the contralateral side by $24 \mathrm{hr}$ after axotomy (Fig. 2F). This increase peaked at 8-60-fold at 7 $\mathrm{d}$ postlesion. mRNA levels remained elevated $21 \mathrm{~d}$ after injury, that is, after the regenerating axons had reached their targets. Northern blot analysis (Fig. 3) revealed an increase to about 11 fold by $7 \mathrm{~d}$ after nerve crush (Fig. $2 F$, star).

Rubrospinal neurons. In normal adult midbrain, we found significant GAP-43 hybridization signals in neurons of the substantia nigra, prerubral field, and some smaller neurons of the red nucleus. The normal magnocellular rubrospinal neurons displayed only low signals (Fig. 7B,D). After axotomy, however, the GAP-43 hybridization signal was significantly $(p<0.01)$ increased by $10-20$-fold (Figs. $7 A, C, 9 E, F$ ), and like T $\alpha 1$ tubulin mRNA, this other marker for the cell-body reaction remained elevated beyond the period when actin and total tubulin mRNA levels decreased (Fig. 8). This increased signal was seen for over 7 weeks, though fewer cells appeared to have elevated GAP-43 mRNA as time progressed (data not shown).

\section{Discussion}

In the present study we have demonstrated that axotomized facial motoneurons exhibit decreased hybridization signals with neurofilament probes and increase their hybridization signal when probed with cDNAs specific for actin, $\alpha$ - and $\beta$-tubulin, and GAP-43 mRNAs. The quantitative Northern blot analysis of total cytoplasmic RNA from facial nuclei is in good agreement with these quantitative in situ hybridization data and with our previously published ${ }^{35} \mathrm{~S}$-methionine incorporation measurements (Tetzlaff et al., 1988). These findings confirm and extend previous findings on axotomized peripheral ganglia (Hoffman et al., 1987; Wong and Oblinger, 1987; Goldstein et al., 1988; Hoffman and Cleveland, 1988) and motoneurons (Miller et al., 1989; Muma et al., 1990). In addition, they emphasize that in situ hybridization consistently detects altered mRNA expression and is a suitable tool to analyze changes in gene expression even within the complexity of the CNS. We demonstrate here that rubrospinal neurons show initial changes in cytoskeletal protein and GAP- 43 mRNA expression that are similar to those occurring in facial motoneurons. During the first week after lesion, neuronal content of actin and tubulin mRNAs increased, while the neurofilament messages decreased. However, during the second and following weeks after axotomy, the cellular levels of actin and total tubulin mRNAs decreased to subnormal values, and cell volumes decreased. Nevertheless, the sustained expression of $\mathrm{T} \alpha 1$ tubulin and GAP-43 mRNA during this period indicates that the rubrospinal neurons maintained aspects of the "normal" axotomy response despite the superimposed reduction in overall cytoskeletal mRNA levels and resulting cellular atrophy. These findings were unexpected and are the first evidence that intrinsic mammalian neurons that are entirely confined within the CNS can show initially similar changes in cytoskeletal gene expression to those found in extrinsic facial motoneurons, which regenerate avidly.

Figure 6. Light microscopical radioautography of rubral neurons after in situ hybridization to a radiolabeled $\beta$-tubulin cDNA probe $(A-F)$. The axotomized side is displayed on the left $(A, C, E)$. Dark-field illumination in $A$ and $B$ shows a marked increase in hybridization signal in the caudal red nucleus at $8 \mathrm{~d}$ after axotomy (arrows). Bright-field illumination in $C-F$ shows increased density of silver grains over axotomized chromatolytic rubral neurons $(C)$ at $8 \mathrm{~d}$ after axotomy compared to contralateral $(D)$. At $14 \mathrm{~d}$ after axotomy $(E)$, the axotomized neurons are shrunken, and the signal per cell is reduced compared to contralateral uninjured neurons $(F)$. Scale bars: $100 \mu \mathrm{m}$ for $A$ and $B, \mu \mathrm{m}$ for $C-F$. $G$, Scatterplot of quantitative in situ hybridization of rubrospinal neurons to an $\alpha$-tubulin cDNA probe, $8 \mathrm{~d}$ after spinal hemisection at C3. Symbols are as in Figure $2 D$. In $H$, values above $(8 \mathrm{~d})$ or below ( $14 \mathrm{~d}$ and $21 \mathrm{~d})$ the short broken lines are significantly different from contralateral. 


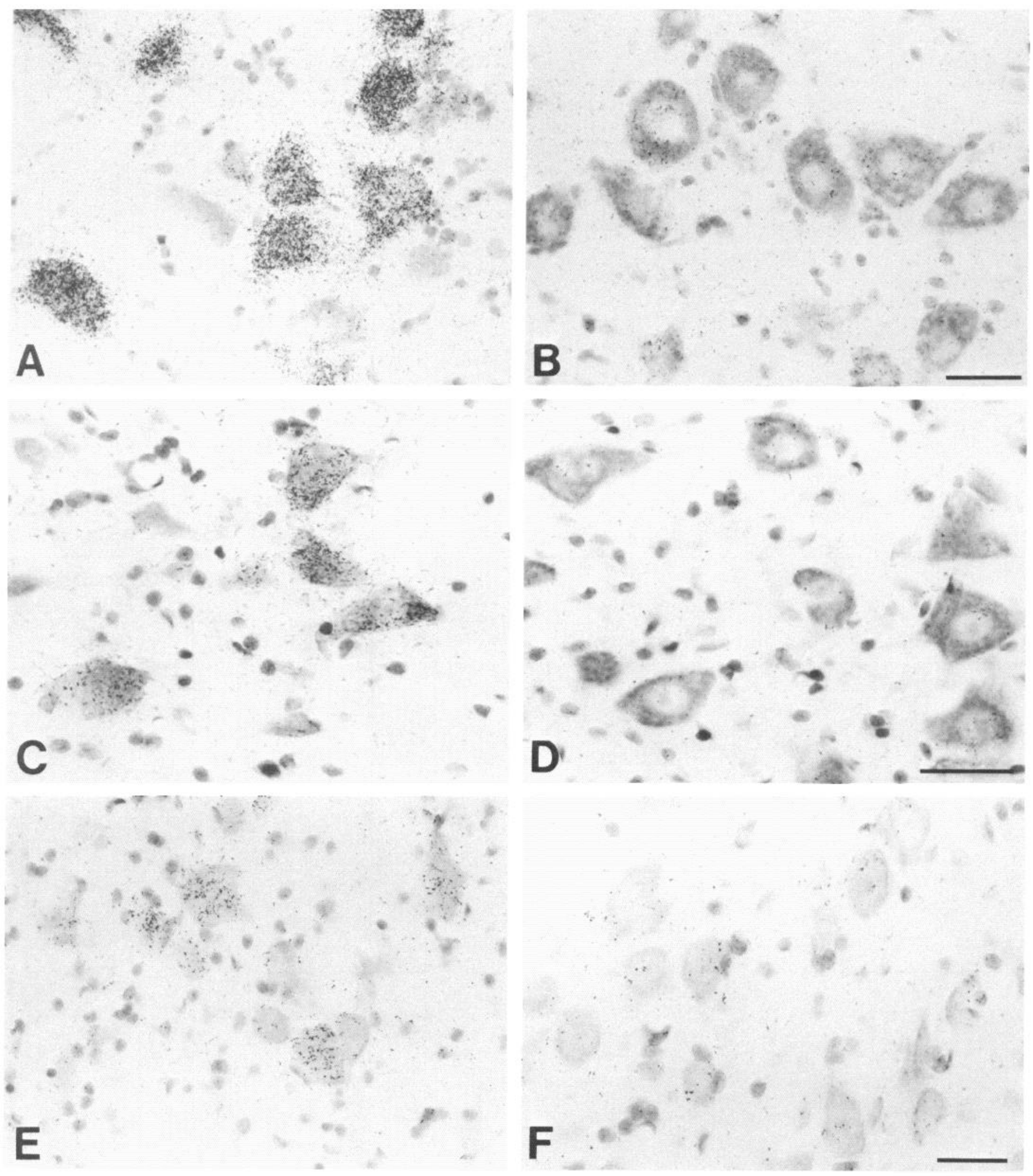

Figure 7. Light microscopical radioautography of rubrospinal neurons after in situ hybridization to a radiolabeled cDNA probe specific for GAP$43(A-D)$ and T $\alpha 1$ tubulin $(E, F)$. The axotomized side is displayed on the left $(A, C, E)$. The GAP-43 in situ hybridization signals over axotomized rubral neurons were significantly increased at $8 \mathrm{~d}(A)$ and $21 \mathrm{~d}(C)$ after axotomy. Note a decrease in cell size after $21 \mathrm{~d}$. The T $\alpha 1$ tubulin signal is clearly increased over axotomized rubrospinal neurons at $8 \mathrm{~d}$ after lesion $(E, F)$. Scale bars, $50 \mu \mathrm{m}$. 
$T \propto 18 d$

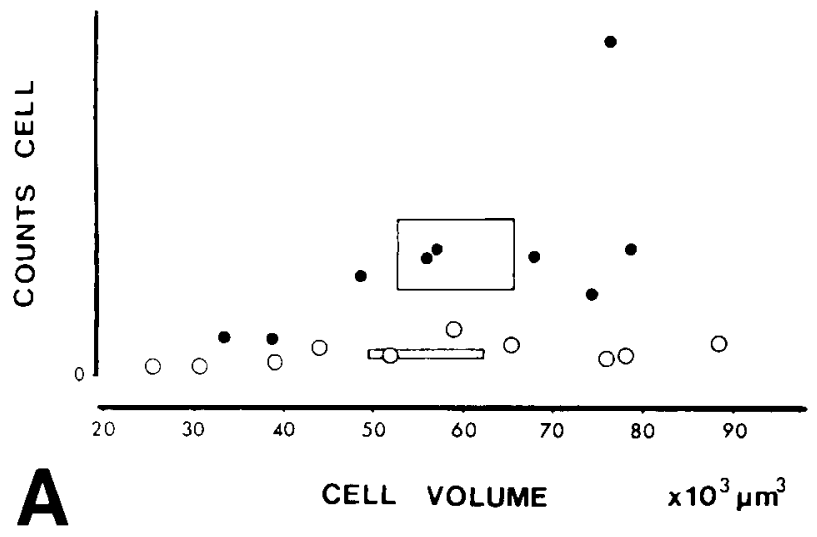

To1 2ld

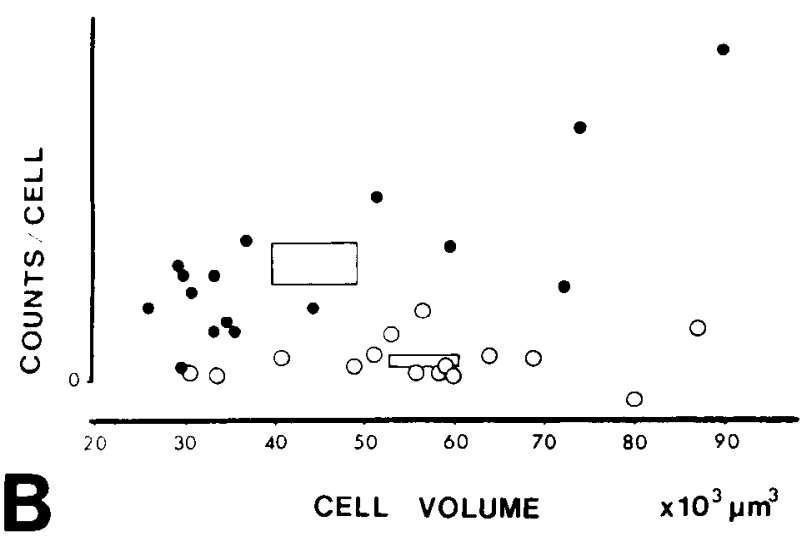

Ta1-TUBULIN

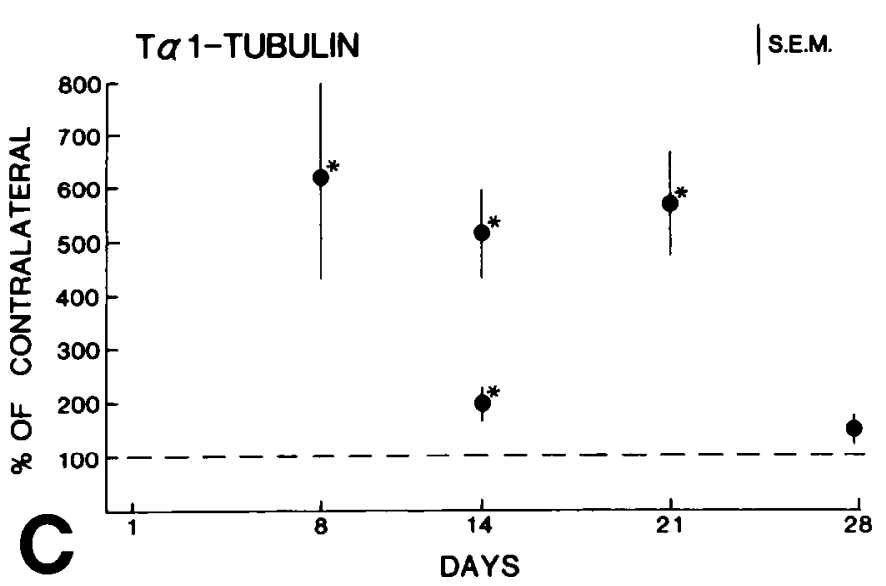

GAP 43 8d

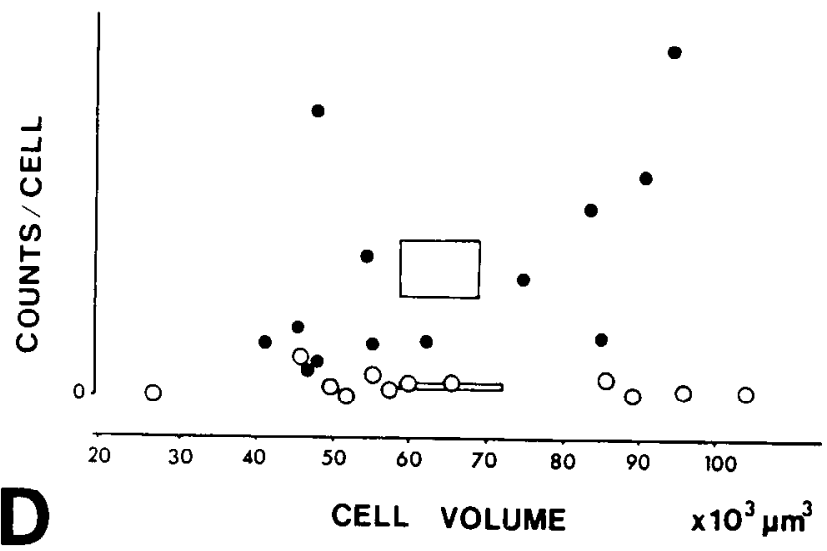

GAP $43 \quad 210$

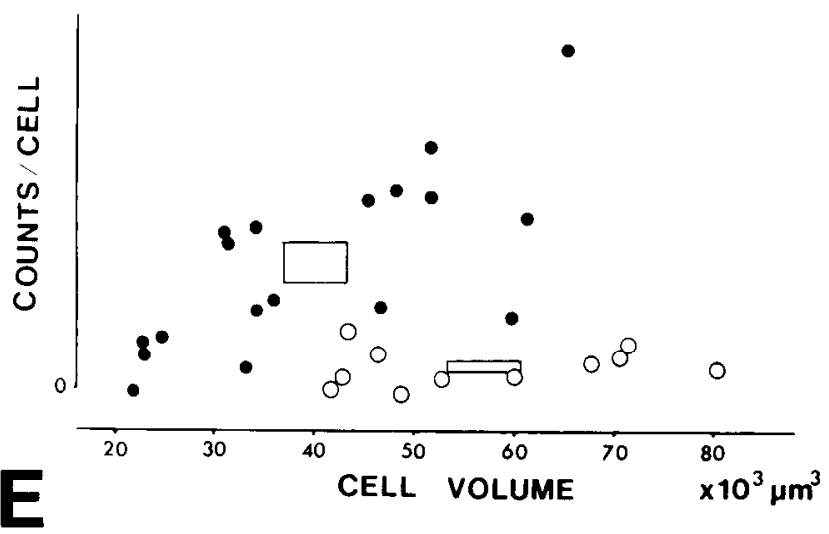

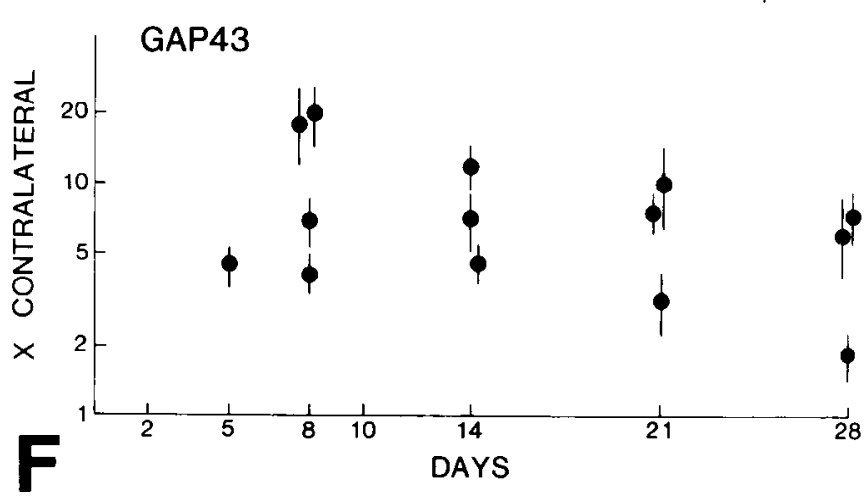

Figure 8. $A$ and $B$, Scatter plot of quantitative in silu hybridization of rubral neurons to a cDNA probe containing the noncoding region of the T $\alpha 1$ tubulin mRNA $8 \mathrm{~d}(A)$ and $21 \mathrm{~d}(B)$ after spinal hemisection at C3. Symbols are as in Figure $2 D$. Note the increase in counts/cell but not in cell size at $8 \mathrm{~d}$ and the increase in counts but decrease in cell size at $21 \mathrm{~d}$. $C$, Changes in mean counts/cell as in Figure $2 A-C$. ${ }^{*}$, significantly different from contralateral. $D$ and $E$. Scatter plot of quantification of $i$ situ hybridization of rubral neurons to a GAP-43 cDNA probe, $8 \mathrm{~d}$ and $21 \mathrm{~d}$ after spinal hemisection at $C 3$. Note the increase in counts/cell but not in cell size at $8 \mathrm{~d}$ and the increase in counts but decrease in cell size at $21 \mathrm{~d}$. $F$, Changes in mean counts/cell as in Figure $2 F$. Note the logarithmic scale. All points are significantly different from contralateral.

Until now, the response of injured rubrospinal neurons was thought to be largely "regressive" in character (Barron, 1983a,b, 1989). These neurons react with central chromatolysis or chromophobia after cervical lesion and show typical signs of cellular atrophy: cytoplasmic, nuclear, and nucleolar shrinkage (Barron, 1983a,b). However, they do not die (Prendergast and Stelzner, 1976; Egan et al., 1977; Barron et al., 1989). Axotomized rubral neurons incorporate less tritiated leucine from $5 \mathrm{~d}$ on than their nonaxotomized counterparts (Barron et al., 1976). Similarly, there is no increased deoxyglucose incorporation in the axotomized red nucleus at any timepoint 1-30 d after a high cervical lesion (Rodichok et al., 1984), in contrast to the increase observed in most injured neurons projecting into the PNS (Kreutzberg and Emmert, 1980; Singer and Mehler, 1980; Smith et al., 1984). 


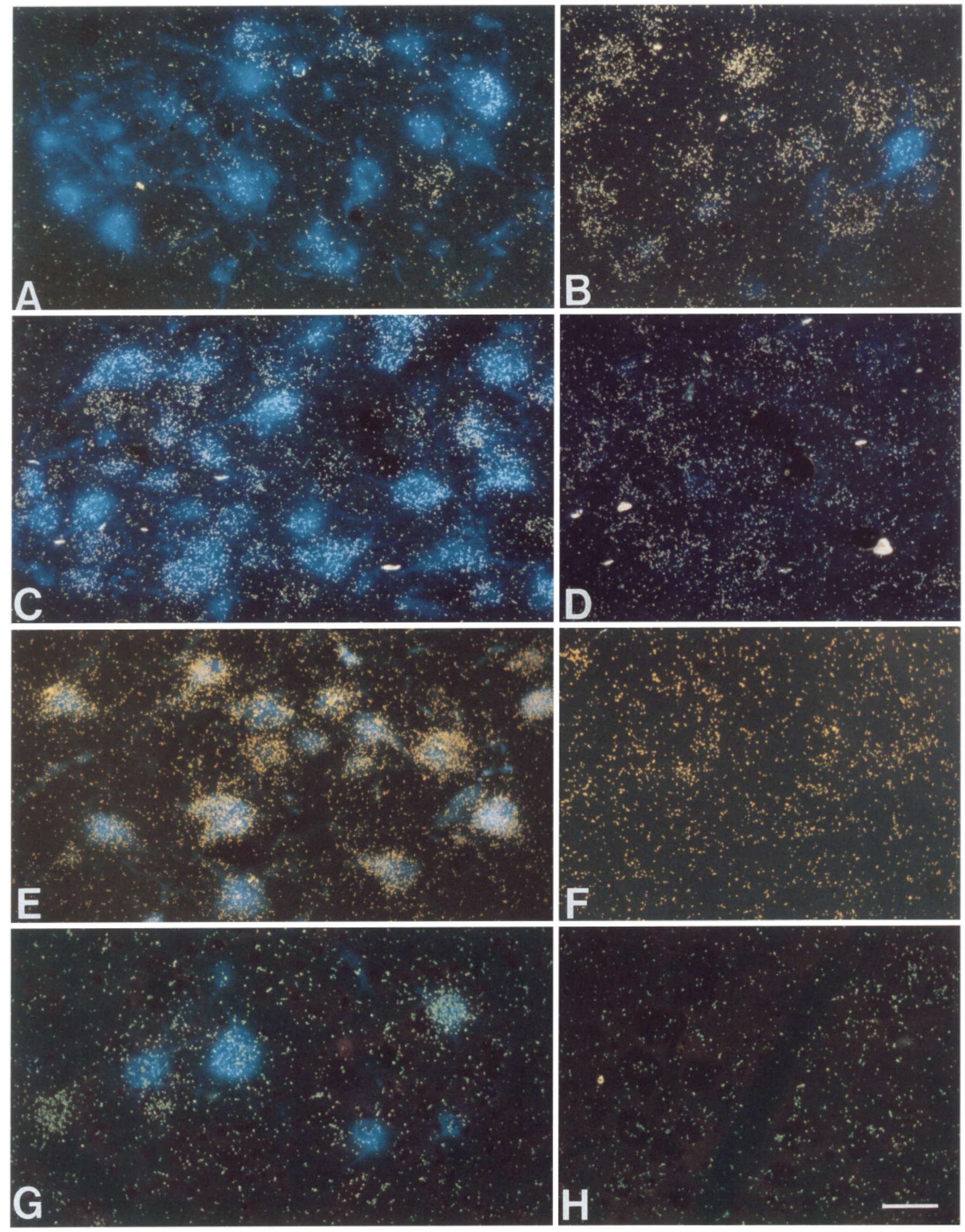


Quantitative microspectrophotometry used for RNA measurement in rat and feline rubral neurons (Barron et al., 1977; Barron, 1989) showed progressive reductions in cytoplasmic and nucleolar RNA content after axotomy. Whether the onset of the cytoplasmic, nuclear, and nucleolar atrophy is already detectable by the first few days postlesion (Barron et al., 1989), or whether a transitory increase in cell size occurs (Egan et al., 1977), is controversial. The early findings by Cole and collaborators (Hanson et al., 1976) supported a transitory regenerative response of rubral neurons after axonal lesions. These authors described an increase of TPNH diaphorase reaction during the first week after axotomy followed by a decrease at later time points. Our present study clearly emphasizes and extends this view of an initial regenerative response. We demonstrated that the reaction of rat rubral neurons to axotomy is not initially regressive, but "regenerative," with the initial mRNA expression changes qualitatively identical to those of facial motoneurons. These regenerative changes may not be apparent when total RNA changes are measured (Barron et al., 1977, 1989) because the increase in actin and tubulin mRNAs may be masked by the decrease in neurofilament mRNAs. Thus, total mRNA levels and protein synthesis may not change initially or may even decrease, depending on the ratio of synthesis of actin plus tubulin versus neurofilament proteins. The reduced $\mathrm{mRN} \Lambda$ levels for all three cytoskeletal proteins at later time points are consistent with reduced total RNA levels in rubral neurons (Barron, 1989). Nevertheless, the sustained expression of $\mathrm{T} \alpha \mathbf{1}$ tubulin and GAP-43 clearly indicate that the regeneration response is not aborted at later stages. Thus, this developmental mode of gene expression typically found in regenerating peripheral neurons (Hoffman and Cleveland, 1988; Miller et al., 1989) can also be expressed and sustained in intrinsic CNS neurons.

These findings may help to explain the regenerative capacity of rubrospinal neurons. A significant number of rubrospinal neurons regenerated into peripheral nerve transplants when these were implanted into the lesioned cervical spinal cord (Richardson et al., 1984). The present study supports the hypothesis that those CNS neurons able to initiate the regeneration-associated changes in gene expression are able to grow their axons into a permissive environment. For GAP-43, the correlation between its expression and capacity to regenerate has been reported in a variety of examples in the PNS, while in the CNS this correlation was largely supported by negative examples (for review, see Skene, 1989). Lack of increased axonal transport of GAP43 has been observed in the optic nerve and corticospinal tract of rodents (Skene and Willard, 1981; Kalil and Skene, 1986; Reh et al., 1987; for review, see Skene, 1989), supporting the view that the failure of axonal regeneration within these CNS tracts is related to the failure to express regeneration-associated proteins like GAP-43. Indeed, peripheral nerve transplants to the intracranial optic nerve or to the spinal cord failed to support regeneration of retinal ganglion cells or corticospinal cells, re- spectively (Richardson et al., 1982, 1984). However, two preliminary reports (Freeman et al., 1986; Lozano et al., 1987) indicated that GAP-43 can be expressed by axotomized retinal ganglion cells in rodents. The reason for discrepancies with earlier negative findings is most likely the effect of the distance from the lesion site to the cell bodies. The study of Lozano et al. (1987) on retinal ganglion cells was done with intraorbital lesions of the optic nerve, while previous investigators used intracranial lesions (Skene and Willard, 1981). Rat retinal ganglion cells can grow into nerves transplanted directly behind the eye (Vidal-Sanz et al., 1987). Our present report shows a clear increase in GAP-43 mRNA in rubrospinal neurons after a cervical lesion of the spinal cord, but preliminary findings indicate that this is not seen with thoracic lesions (Tetzlaff et al., 1990). A significant number of rubrospinal neurons regenerate into cervical but not into thoracic transplants (Richardson et al., 1984). Thus, even within the same CNS neuronal system, the response to axotomy might be largely dependent on the distance from the lesion to the cell body and/or the associated sparing of sustaining collaterals. Although none of these neuronal systems regenerate within the CNS, their capacity to grow into a peripheral nerve transplant appears to be correlated with their ability to express GAP-43. It is now necessary to understand the molecular mechanisms that trigger the regeneration-associated response in gene expression, in order to enhance the neuronal propensity for growth into an environment that has been rendered permissive.

The signal for axotomy that leads to the so-called "cell-body reaction" is not known, and a variety of possibilities have been considered for peripheral neurons (Cragg, 1970). We recognize that different components of this "cell-body reaction" are probably regulated from several separately controlled genes that respond to different molecular signals (Verge et al., 1990a,b). These signals may include positive signals such as factors from the injured peripheral stump or negative signals such as the interruption of a normally retrogradely transported factor, or the premature return of an anterogradely transported substance (for review, see Bisby, 1984). The present study indicates that for cytoskeletal proteins and for GAP-43 these axotomy signals are likely to be similar in the lesioned CNS and PNS. Thus, the signal(s) for axotomy is apparently not a factor specific to the PNS. This is an important finding because the microenvironment of the PNS is permissive to axonal outgrowth, and transplanting peripheral nerve segments into the CNS might itself have triggered a growth response. However, the present study demonstrated that at least those parameters of the neuronal cell body response tested so far were induced by the axotomy.

The second major finding of this study is the decreased expression of cytoskeletal mRNAs in rubrospinal neurons during the second and third weeks after axotomy. This is in distinct contrast to facial motoneurons. It is unclear whether this decrease is a cause or an effect of the failure of rubrospinal neurons to regenerate within the spinal cord. It is conceivable that the

Figure 9. Retrograde labeling of axotomized rubrospinal neurons combined with in situ hybridization for NFM $(A, B)$, $\alpha$-tubulin $(C, D)$, GAP$43(E, F)$, and $\mathrm{T} \alpha 1$ tubulin $(G, H)$. The axotomized side is on the left, and the uninjured contralateral side is on the right. Fluorescence illumination was used to photograph the fast blue $(A, C, G)$ or Fluoro-gold $(E)$ label, and simultaneously dark-field illumination was used to reveal the silver grains representing the in situ hybridization signal. One neuron in $B$ is both labeled and displaying lower levels of NFM mRNA than the adjacent unlabeled neurons. Apparently, its axon was not crossed, and so it was axotomized and labeled, representing an exception. $A-F$ are $7 \mathrm{~d}$, and $G$ and $H, 7$ weeks after axotomy. Note the increased $\mathrm{T} \alpha 1$ tubulin label (silver grains) in some but not all fast blue-labeled neurons $(G)$. Some cells in $G$ show increased silver grain density, but were only faintly labeled with fast blue and lost their label during hybridization. Scale bar, $50 \mu \mathrm{m}$. 
lack of actin and tubulin supply from the cell body leads to an aborted axonal sprouting response during the second week. We do not know the reason for this "regressive" cell-body response and can only presume that either a lack of some trophic factor or the active depression by some inhibiting factor is involved. Growth inhibiting molecules have recently been identified (Caroni and Schwab, 1988a,b), and treatment with antibodies to these $35-\mathrm{kDa}$ and $250-\mathrm{kDa}$ proteins enhanced outgrowth of some axons in the lesioned spinal cord of postnatal rats (Schnell and Schwab, 1990). These inhibitory molecules, which have been shown to act locally at the growth cone, may also inhibit directly or indirectly the neuronal gene expression response to injury. Our study indicates that such inhibitory factors within the CNS do not interfere with the signal for axotomy and the initiation of a regenerative response, but they could interfere with the maintenance of this response.

Alternatively, the regressive cell-body response may be due to the fact that trophic support of rubrospinal neurons has been interrupted by disconnecting them from their target. The CNS environment might not provide enough trophic substitute compared to the PNS, where Schwann cells in the distal nerve stump and neuroma upregulate the production of NGF and other trophic molecules (Richardson and Ebendal, 1982; Heumann et al., 1987). Those rubrospinal neurons with regenerating axons into peripheral nerve grafts did not appear to be atrophic (Richardson et al., 1984). It will be interesting to determine whether regeneration of rubrospinal neurons into a peripheral nerve graft is associated with a sustained increase in tubulin and actin expression. The combination of in situ hybridization with retrograde labeling through a peripheral nerve graft will allow us to investigate this question.

\section{References}

Aguayo AJ (1985) Axonal regeneration from injured neurons in the adult mammalian central nervous system. In: Synaptic plasticity (Cotman CW, ed), pp 457-484. New York: Guildford.

Aguayo AJ (1987) Growth and connectivity of axotomized retinal neurons in adult rats with optic nerves substituted by PNS grafts linking the eye and the midbrain. Ann NY Acad Sci 495:1-9.

Barron KD (1983a) Axon reaction and central nervous system regeneration. In: Nerve, organ and tissue regeneration: research perspectives (Seil FJ, ed), pp 3-36. New York: Academic.

Barron KD (1983b) Comparative observations on the cytologic reactions of central and peripheral nerve cells to axotomy. In: Spinal cord reconstruction (Kao CC, Bunge RP, Reier PJ, eds), pp 7-40. New York: Raven.

Barron KD (1989) Neuronal responses to axotomy: consequences and possibilities for rescue from permanent atrophy or cell death. In: Neural regeneration and transplantation (Seil FJ, ed), pp 79-99. New York: Liss.

Barron KD, Dentinger MP, Nelson LR, Scheibly ME (1976) Incorporation of tritiated leucine by axotomized rubral neurons. Brain Res 116:251-266.

Barron KD, Schreiber SS, Cova JL, Scheibly ME (1977) Quantitative cytochemistry of RNA in axotomized feline rubral neurons. Brain Res 130:469-481.

Barron KD, McGuinness C, Misantone LJ, Zanakis MF, Graftstein B, Murray M (1985) RNA content of normal and axotomized retinal ganglion cells of rat and goldfish. J Comp Neurol 236:265-273.

Barron KD, Dentinger MP, Krohel G, Easton SK, Mankes R (1986) Qualitative and quantitative ultrastructural observations on retinal ganglion cell layer of rat after intraorbital nerve crush. J Neurocytol 15:345-362.

Barron KD, Banerjee M, Dentinger MP, Scheibly ME, Mankes R (1989) Cytological and cytochemical (RNA) studies on rubral neurons after unilateral rubrospinal tractotomy: the impact of GM1 ganglioside administration. J Neurosci Res 22:331-337.
Basi GS, Jacobson RC, Virag I, Schilling J, Skene JHP (1987) Primary structure and transcriptional regulation of GAP-43, a protein associated with nerve growth. Cell 49:785-791.

Benowitz LI, Routtenberg A (1987) A membrane phosphoprotein associated with neural development, axonal regeneration, phospholipid metabolism and synaptic plasticity. Trends Neurosci 10:527532.

Berry M, Rees L, Sievers J (1986) Unequivocal regeneration of rat optic nerve axons into sciatic nerve isografts. In: Neural transplantation and regeneration (Das GD, Wallace RD, eds), pp 63-79. New York: Springer.

Bisby MA (1984) Retrograde axonal transport and nerve regeneration. In: Advances in neurochemistry, Vol $6, \Lambda$ xonal transport (Elam JS, Canacalon $P$, eds), pp 45-67. New York: Plenum.

Bisby MA (1988) Dependence of GAP-43 (B50, F1) transport on axonal regeneration in rat dorsal root ganglion neurons. Brain Res 458 : 157-161.

Bray GM, Aguayo AJ (1989) Exploring the capacity of CNS neurons to survive injury, regrow axons, and form new synapses in adult mammals. In: Neural regeneration and transplantation (Seil FJ, ed), pp 67-78. New York: Liss.

Brown, LT (1974) Rubrospinal projections in the rat. J Comp Neurol 154:169-188.

Burrell HR, Heacock AM, Water RD, Agranoff BW (1979) Increased tubulin messenger RNA in the goldfish retina during optic nerve regeneration. Brain Res 168:628-632.

Caroni P, Schwab ME (1988a) Antibody against myelin-associated inhibitor of neurite growth neutralizes nonpermissive substrate properties of CNS white matter. Neuron 1:85-96.

Caroni P, Schwab ME (1988b). Two membrane protein fractions from rat central myelin with inhibitory properties for neurite growth and fibroblast spreading. J Cell Biol 106:1281-1288.

Cragg BG (1970) What is the signal for chromatolysis? Brain Res 23: $1-21$.

Egan DA, Flumerfeld BA, Gwyn DG (1977) Axon reaction in the red nucleus of the rat. Perikaryal volume changes and the time course of chromatolysis following cervical and thoracic lesions. Acta Neuropathol (Berl) 37:13-19.

Feinberg AP, Vogelstein B (1983) A technique for radiolabeling DNA restriction endonuclease fragments to high specific activity. Anal Biochem 13:6-13.

Freeman JA, Bock S, Deaton M, McGuire B, Norden JJ, Snipes GJ (1986) Axonal and glial proteins associated with development and response to injury in the rat and goldfish optic nerve. Exp Brain Res [Suppl] 13:34-47.

Goldstein ME, Weiss SR, Lazzarini RA, Shneidman PS, Lees JF, Schlaepfer W (1988) mRNA levels of all three neurofilament proteins decline following nerve transection. Mol Brain Res 3:287-292.

Grafstein B (1983) Chromatolysis reconsidered: a new view of the reaction of the nerve cell body to axon injury. In: Nerve, organ, and tissue regeneration: research perspectives (Seil FJ, ed), pp 37-50. New York: Academic.

Grafstein B (1986) The retina: a model for cell biology studies, Pt II (Adler R, Farber DB, eds), pp 275-335. New York: Academic.

Grafstein B, McQuarrie IG (1978) The rolc of the nerve cell body in axonal regeneration. In: Neuronal plasticity (Cotman $\mathrm{CW}$, ed), pp 155-195. New York: Raven.

Greenberg SG, Lasek RJ (1988) Neurofilament protein synthesis in DRG neurons decreases more after peripheral axotomy than after central axotomy. J Neurosci 8:1739-1746.

Hall ME (1982) Changes in synthesis of specific proteins in axotomized dorsal root ganglia. Exp Neurol 76:83-93.

Hall ME, Wilson DL, Stone GC (1978) Changes in synthesis of specific proteins following axotomy: detection with two-dimensional gel electrophoresis. J Neurobiol 9:353-366.

Hanson M, Cole M, Molinski JA (1976) Retrograde oxidative reactions after section of the rubrospinal tract. Perspect Biol Med 19:381387.

Heumann R, Korsching S, Bandtlow C, Thoenen H (1987) Changes of nerve growth factor synthesis in nonneuronal cells in response to sciatic nerve transection. J Cell Biol 104:1623-1631.

Hoffman PN (1989) Expression of GAP-43, a rapidly transported growth-associated protein, and class II beta tubulin, a slowly transported cytoskeletal protein, are coordinated in regenerating neurons. J Neurosci 9:893-897. 
Hoffman PN, Cleveland DW (1988) Neurofilament and tubulin expression recapitulates the developmental pattern during axonal regeneration: induction of a specific $\beta$-tubulin isotype. Proc Natl Acad Sci USA 84:4530-4533.

Hoffman PN, Cleveland DW, Griffith JW, Landes PW, Cowan NJ, Price DL (1987) Neurofilament gene expression: a major determinant of axonal calibre. Proc Natl Acad Sci USA 84:3472-3476.

Huisman AM, Kuypers HGJM, Verburgh CA (1981) Quantitative differences in collateralization of the descending spinal pathways from red nucleus and other brain stem cell groups in rat as demonstrated with the multiple fluorescent retrograde tracer technique. Brain Res 209:271-286.

Julien JP, Meyer D, Flavell D, Hurst J, Grosveld F (1986) Cloning and developmental expression of the murine neurofilament gene family. Mol Brain Res 1:243-250.

Kalil K, Skene JHP (1986) Elevated synthesis of an axonally transported protein correlates with axon outgrowth in normal and injured pyramidal tracts. J Neurosci 6:2563-2570.

Kreutzberg GW (1982) Acute neuronal reaction to injury. In: Repair and regeneration of the nervous system (Nicholls JG, ed), pp 57-69. Berlin: Springer.

Kreutzberg GW, Emmert H (1980) Glucose utilization of motor nuclei during regeneration: a $\left[{ }^{14} \mathrm{C}\right] 2$-deoxyglucose study. Exp Neurol 70:712716.

Kuypers HGJM, Huisman AM (1984) Fluorescent neuronal tracers. Adv Cell Neurobiol 5:307-335.

Lemischka IR, Farmer S, Racaniello VR, Sharp PA (1981) Nucleotide sequence and evolution of a mammalian $\alpha$-tubulin mRNA. J Mol Biol 150:101-120.

Lewis SA, Cowan NJ (1985) Genetics, evolution, and expression of the 68,000 -mol-wt neurofilament protein: isolation of a cloned cDNA probe. J Cell Biol 100:843-850.

Lewis SA, Lee MG-S, Cowan NJ (1985) Five mouse tubulin isotypes and their regulated expression during development. J Cell Biol 101: $852-861$

Lieberman AR (1971) The axon reaction: a review of the principal features of perikaryal responses to axon injury. Int Rev Neurobiol 14:49-124.

Lieberman AR (1974) Some factors affecting retrograde neuronal responses to axonal lesions. In: Essays on the nervous system (Bellairs R, Gray EG, eds), pp 71-105. Oxford: Clarendon.

Lozano AM, Doster SK, Aguayo AJ, Willard MB (1987) Immunoreactivity to GAP-43 in axotomized and regenerating retinal ganglion cells of adult rats. Soc Neurosci Abstr 13:1389.

Maniatis T, Fritsch EF, Sambrook J (1982) Molecular cloning. Cold Spring Harbor, NY: Cold Spring Harbor Laboratory.

Miller FD, Naus CCG, Durand M, Bloom FE, Milner RJ (1987) Isotypes of $\alpha$-tubulin are differentially regulated during neuronal maturation. J Cell Biol 105:3065-3073.

Miller FD, Tetzlaff W, Bisby MA, Fawcett JW, Milner RJ (1989) Rapid induction of the major embryonic $\alpha$-tubulin mRNA, in adults following neuronal injury. J Neurosci 9:1452-1463.

Minty AJ, Caravatis M, Robert B, Cohen A, Daubas P, Weydert A, Gros F, Buckingham ME (1981) Mouse actin messenger RNAs. J Biol Chem 256:1008-1014.

Muma NA, Hoffman PN, Slunt HH, Applegate MD, Lieberburg I, Price DL (1990) Alterations in levels of mRNAs coding for neurofilament protein subunits during regeneration. Exp Neurol 107:230-235.

Neumann D, Scherson T, Ginzburg I, Littauer UZ, Schwartz M (1983) Regulation of mRNA levels for microtubule proteins during nerve regeneration. FEBS Lett 162:270-276.

Oblinger MM, Lasek RJ (1988) Axotomy-induced alterations in the synthesis and transport of neurofilaments and microtubules in the dorsal root ganglion cells. J Neurosci 8:1747-1758.

Oblinger MM, Wong J, Parysek LM (1989) Axotomy-induced changes in the expression of a type III neuronal intermediate filament gene. J Neurosci 9:3766-3775.

Pearson RCA, Taylor N, Snyder SH (1988) Tubulin messenger RNA: in situ hybridization reveals bilateral increases in hypoglossal and facial nuclei following nerve transection. Brain Res 463:245-249.

Politis MJ, Spencer PS (1986) Regeneration of rat optic axons into peripheral nerve grafts. Exp Neurol 91:52-59.

Prendergast J, Stelzner DJ (1976) Changes in the magnocellular portion of the red nucleus following thoracic hemisection in the neonatal and adult rat. J Comp Neurol 166:163-172.
Quesada MH, Millar DB, Smejkal R (1986) Tubulin synthesis in the regenerating rat superior cervical ganglion: a biphasic response. $J$ Neurobiol 17:77-82.

Ramon y Cajal S (1959) Degeneration and regeneration of the nervous system. (New York: Oxford UP, 1928.) Reprint (May RM, trans, ed). New York: Hafner.

Rave N, Crkvenjakov R, Boedtker H (1979) Identification of procollagen mRNAs transferred to diazobenzyloxymethyl paper from formaldehyde agarose gels. Nucleic Acids Res 6:3559-3567.

Redshaw JD, Bisby MA (1984a) Proteins of fast axonal transport in the regenerating hypoglossal nerve of the rat. Can J Physiol Pharmacol 62:1387-1393.

Redshaw JD, Bisby MA (1984b) Fast axonal transport in central nervous system and peripheral nervous system axons following axotomy. J Neurobiol 15:109-117.

Reh TA, Redshaw JD, Bisby MA (1987) Axons of the pyramidal tract do not increase their transport of growth-associated proteins after axotomy. Mol Brain Res 2:1-6.

Reid JM, Gwyn DG, Flumerfelt BA (1975a) A cytoarchitectonic and Golgi study of the red nucleus in the rat. J Comp Neurol 162:337362.

Reid JM, Flumerfeldt BA, Gwyn DG (1975b) An ultrastructural study of the red nucleus in the rat. J Comp Neurol 162:363-386.

Richardson PM, Ebendal T (1982) Nerve growth activities in rat peripheral nerve. Brain Res 246:57-64.

Richardson PM, McGuinness UM, and Aguayo AJ (1980) Axons from CNS neurons regenerate into PNS grafts. Nature 284:264-265.

Richardson PM, Issa VMK, Shemie S (1982) Regeneration and retrograde degeneration of axons in the rat optic nerve. $J$ Neurocytol 11:949-966.

Richardson PM, Issa VMK, Aguayo AJ (1984) Regeneration of long spinal axons in the rat. J Neurocytol 13:165-182.

Rodichok LD, Barron KD, Popp AJ, Dentiger MP, Scheibly ME (1984) Glucose utilization is unchanged in red nucleus after axotomy. Brain Res 324:253-259.

Schibler K, Tosei M, Pittet A-C, Fabiani L, Wellames P (1980) Tissuespecific expression of mouse $\alpha$-amylase genes. J Mol Biol 142:93116.

Schnell L, Schwab ME (1990) Axonal regeneration in the rat spinal cord produced by an antibody against myelin associated neurite growth inhibitors. Nature 343:269-272.

Singer P, Mehler S (1980) 2-Deoxy $\left[{ }^{14} \mathrm{C}\right]$ glucose uptake in the rat hypoglossal nucleus after nerve transection. Exp Neurol 69:617-626.

Skene JHP (1989) Axonal growth-associated proteins. Annu Rev Neurosci 12:127-156.

Skene JHP, Willard M (1981) Axonally transported proteins associated with axon growth in rabbit central and peripheral nervous systems. J Cell Biol 89:96-103.

Smith CB, Crane AM, Kadekaro M, Agranoff BW, Sokoloff L (1984) Stimulation of protein synthesis and glucose utilization in the hypoglossal nucleus induced by axotomy. J Neurosci 4:2489-2496.

Tesser P, Jones PS, Schechter N (1986) Elcvatcd lcvels of retinal neurofilament mRNA accompany optic nerve regeneration. J Neurochem 47:1235-1243.

Tetzlaff W, Bisby MA (1989) Neurofilament elongation into regenerating facial nerve axons. Neurosci 29:659-666.

Tetzlaff W, Kreutzberg GW (1984) Enzyme changes in the rat facial nucleus following a conditioning lesion. Exp Neurol 85:547-564.

Tetzlaff W, Kreutzberg GW (1985) Ornithine decarboxylase in motoneurons during regeneration. Exp Neurol 89:679-688.

Tetzlaff W, Graeber MB, Kreutzberg GW (1986) Reaction of motoneurons and their microenvironment to axotomy. Exp Brain Res [Suppl] 13:3-8.

Tetzlaff W, Bisby MA, Kreutzberg GW (1988) Changes in cytoskeletal protein changes in the rat facial nucleus following axotomy. J Neurosci 8:3181-3189.

Tetzlaff W, Zwiers H, Lederis K, Cassar L, Bisby MA (1989) The axonal transport and localization of B50/GAP-43-like immunoreactivity in regenerating sciatic and facial nerves of the rat. $J$ Neurosci 9:1303-1313.

Tetzlaff W, Tsui BJ, Balfour JK (1990) Rubrospinal neurons increase GAP-43 and tubulin mRNA after cervical but not after thoracic axotomy. Soc Neurosci Abstr 16:338.

Thomas PS (1980) Hybridization of denatured RNA and small DNA 
fragments transferred to nitrocellulose. Proc Natl Acad Sci USA 77: 5201-5215.

Van der Zee CEEM, Nielander HB, Vos JP, Lopes da Silva S, Verhaagen J, Oestreicher AB, Schrama LH, Schotman P, Gispen WH (1989) Expression of growth-associated protein B50 (GAP-43) in dorsal root ganglia and sciatic nerve during regenerative sprouting. J Neurosci 9: 3505-3512.

Verge VMK, Tetzlaff W, Richardson PM, Bisby MA (1990a) Correlation between GAP-43 and nerve growth factor receptors in rat sensory neurons. J Neurosci 10:926-934.

Verge VMK, Tetzlaff W, Bisby MA, Richardson PM (1990b) Influence of nerve growth factor on neurofilament gene expression in mature primary sensory neurons. J Neurosci 10:2018-2025.

Vidal-Sanz M, Bray GM, Villegas-Perez MP, Thanos S, Aguayo AJ (1987) Axonal regeneration and synapse formation in the superior colliculus by retinal ganglion cells in the adult rat. J Neurosci 7:28942909.

Villasante A, Wang D, Dobner P, Dolph P, Lewis SA, Cowan NJ (1986) Six mouse $\alpha$-tubulin mRNAs encode five distinct isotypes: testisspecific expression of two sister genes. Mol Cell Biol 6:2409-2419.

Villegas-Perez MP, Vidal-Sanz M, Bray GM, Aguayo AJ (1988) Influences of peripheral nerve grafts on the survival and regrowth of axotomized retinal ganglion cells in adult rats. J Neurosci 8:265-280.

Wong J, Oblinger MM (1987) Changes in neurofilament gene expression occur after axotomy of dorsal root ganglion neurons: an in situ hybridization study. Metab Brain Dis 2:291-303.

Xu XM, Martin GF (1990) The response of rubrospinal neurons to axotomy in the adult opossum, Didelphis virginiana. Exp Neurol 108: $46-54$. 